\title{
TARGETING STRIATAL METABOTROPIC GLUTAMATE RECEPTOR TYPE 5 IN PARKINSON'S DISEASE: BRIDGING MOLECULAR STUDIES AND CLINICAL TRIALS
}

\author{
Vallano A. ${ }^{1,2}$, Fernández-Dueñas V. ${ }^{2}$, García-Negredo G. ${ }^{2}$, Quijada MA ${ }^{1}$, Simón \\ CP ${ }^{1}$, Cuffí ML ${ }^{2}$, Carbonell L. ${ }^{2}$, Sánchez S. ${ }^{2}$, Arnau JM. ${ }^{1,2}$ \& Ciruela F. ${ }^{2}$
}

${ }^{1}$ Servei de Farmacologia Clínica, Hospital Universitari de Bellvitge-ICS, IDIBELL. ${ }^{2}$ Unitat de Farmacologia, Departament Patologia i Terapèutica Experimental, Facultat de Medicina, IDIBELL, Universitat de Barcelona, L'Hospitalet de Llobregat, 08907 Barcelona, Spain.

Running title: $\mathrm{mGlu}_{5} \mathrm{R} \&$ Parkinson's disease

Number of pages: 43

Abstract: 130 words

Main text: 4474 words

References: 105 references

Fig. legends: 692 words

Number of figures: 3

Number of tables: 6

$\begin{array}{ll}\text { Corresponding author: } & \text { Francisco Ciruela, Ph.D. } \\ \text { University of Barcelona } & \text { Unitat de Farmacologia } \\ & \text { Dept. de Patologia i Terapeutica Experimental } \\ & \text { Facultat de Medicina (Campus de Bellvitge) } \\ & \text { Pavelló de Govern, Av. Feixa Llarga, s/n } \\ & \text { 08907 L'Hospitalet del Llobregat, Barcelona, Spain } \\ & \text { Tel: +34 (93) 402 4280/ +34 (93) 403 5820 } \\ & \text { Fax: +34 (93) 402 9082 } \\ \text { E-mail: fciruela@ub.edu }\end{array}$

Keywords: $\mathrm{mGlu}_{5} \mathrm{R}$; Parkinson's disease; GPCR oligomerization; Clinical trial; AFQ056. 


\begin{abstract}
Metabotropic glutamate (mGlu) receptors are $\mathrm{G}$ protein-coupled receptors expressed primarily on neurons and glial cells modulating the effects of glutamatergic neurotransmission. The pharmacological manipulation of these receptors has been postulated to be valuable in the management of some neurological disorders. Accordingly, the targeting of $\mathrm{mGlu}_{5}$ receptors as a therapeutic approach for Parkinson's disease (PD) has been proposed, especially to manage the adverse symptoms associated to chronic treatment with classical PD drugs. Thus, the specific pharmacological blocking of $\mathrm{mGlu}_{5}$ receptors constitutes one of the most attractive non-dopaminergicbased strategies for PD management in general and for the L-DOPA-induced diskynesia (LID) in particular. Overall, we provide here an update of the current state of the art of these $\mathrm{mGlu}_{5}$ receptor-based approaches that are under clinical study as agents devoted to alleviate PD symptoms.
\end{abstract}




\section{INTRODUCTION}

The amino acid L-glutamate (Glu) is recognized as the major excitatory neurotransmitter in the mammalian central nervous system (CNS) $[1,2]$. Interestingly, the glutamatyergic system, apart from participating in the fast synaptic transmission, is also involved in neuronal plasticity and higher cognitive brain functions. In addition, excessive Glu can promote neuronal dysfunction and degeneration (i.e. neurotoxicity or excitotoxicity), and it has therefore been implicated in the pathogenesis of several chronic CNS neurodegenerative disorders such as amyotrophic lateral sclerosis, multiple sclerosis, Parkinson's disease (PD) and Alzheimer's disease (AD) [3, 4].

The glutamatergic system is highly sophisticated; a fact evidenced by the exceptional organization of the glutamate receptor subtypes, which include both ionotropic (iGlu) and metabotropic (mGlu) receptor families $[5,6]$. There are three classes of iGlu receptors, namely N-methyl-D-aspartic acid (NMDA) receptor, $\alpha$-amino-3-hydroxy-5methyl-4-isoxazolepropionic acid (AMPA) receptor and kainate receptors [3]. iGlu receptors, localized on neuronal and non-neuronal cells, mediate CNS fast excitatory synaptic transmission and therefore are postulated to play a key role in a large plethora of processes within the brain, spinal cord, retina, and peripheral nervous system [5]. Focusing on mGlu receptors, they are G protein-coupled receptors [7], and on the basis of their sequence similarity and pharmacological profile, are classified into three groups (I,II,III) [6]. Group I includes $\mathrm{mGlu}_{1}$ and $\mathrm{mGlu}_{5}$ receptors, which have quisqualic acid as their most potent agonist, are coupled to $\mathrm{G}_{\mathrm{q}} / \mathrm{G}_{11}$, and after its activation lead to the activation of phospholipase $\mathrm{C}[6]$. Five splice variants of $\mathrm{mGlu}_{1}$ receptor have been described (i.e. $\alpha, \beta_{1}, \beta_{2}, \gamma$ and $\delta$ ) [8], all of them differing in the length of their Cterminal tail, which is thought to play a key role in the subcellular targeting of the receptor $[6,9,10]$. Similarly, two splice variants for the mGlu $_{5}$ receptor have been 
described, namely the $\mathrm{mGlu}_{5 \mathrm{a}}$ and $\mathrm{mGlu}_{5 \mathrm{~b}}$ receptors, which differ in that $\mathrm{mGlu}_{5 \mathrm{~b}}$ receptor has a 33-amino acid insert in the intracellular C-terminal domain [11]. However, no functional differences have been reported between these two variants, although it has been postulated that alternative $\mathrm{mGlu}_{5}$ receptor splicing may contribute to regulatory mechanisms for tissue- and context-specific expression of the $\mathrm{mGlu}_{5}$ receptor gene [12]. Interestingly, $\mathrm{mGlu}_{5}$ receptors are highly expressed within the CNS, thus they have been found in cerebral cortex (i.e. granule cells), hippocampus (i.e. dentate gyrus and pyramidal neurons of the CA1-3 area), olfactory bulb, lateral septum, striatum, nucleus accumbens and inferior colliculus [13]. At the subcellular level, $\mathrm{mGlu}_{5}$ receptors have been mostly found in neuronal postsynaptic elements, showing a perisynaptic and extrasynaptic distribution [14]. Thus, activation of postsynaptic $\mathrm{mGlu}_{5}$ receptors may regulate ion channels functioning and increase the excitability of several types of neurons [15]. In addition, putative presynaptic mGlu $_{5}$ autoreceptors have also been found, for instance in mouse cortical nerve endings [16], to facilitate glutamate exocytosis. On the other hand, group I mGlu receptors have been shown to be specifically involved in corticostriatal synaptic plasticity [17]. For instance, activation of $\mathrm{mGlu}_{1}$ receptor is required for the induction of corticostriatal long-term depression (LTD) [18-20], a fact that is linked to the receptor's ability to modulate intracellular calcium concentration [21]. Or, it has also been shown that both $\mathrm{mGlu}_{1}$ and $\mathrm{mGlu}_{5}$ receptors mediate in corticostriatal long-term potentiation (LTP), since simultaneous blockade of both receptors abolishes this phenomenon [22].

Overall, mGlu receptors play a key role in CNS functioning, thus when the glutamatergic system is deregulated, as it occurs in excitotoxic brain conditions associated to some neurodegenerative diseases, the pharmacological manipulation of these receptors (i.e. blockade of group I or activation of group II and III mGlu 
receptors) has been postulated to exert beneficial effects. Accordingly, in the recent years it has been considered the usefulness of $\mathrm{mGlu}_{5}$ receptor blockade as a nondopaminergic therapeutic approach of PD, specially to manage the adverse symtoms associated to prolonged dopaminergic-based therapy (i.e. dyskinesia and motor fluctuations).

\section{GLUTAMATERGIC NEUROTRANSMISSION AND PARKINSON'S DISEASE}

Parkinson's disease (PD) is one of the most common neurological disorders and affects approximately to $1 \%$ of individuals over the age of 60 . It consists of a progressive systemic neurodegenerative disorder, in which different brain areas are affected (i.e. locus coeruleus, nucleus basalis of Meynert, dorsal raphe nucleus and the dorsal motor nucleus of the vagus), but it is primarily associated with the loss of pigmented dopaminergic neurons located within the pars compacta of the substantia nigra (SNc) [23] (Fig. 1C). The initial symptoms of the pathology (pre-motor phase) are poorly specific (i.e. fatigue, depression, constipation, decreased sense of smell and sleep problem), but when the disease advances (motor phase) the associated features and clinical signs are very well-characterized, including resting tremor, rigidity, bradykinesia, and postural instability [24]. Finally, since PD is a neurodegenerative condition, neuronal death continues beyond the motor phase, and it can affect other brain regions, for instance cortical areas, thus patients may then show cognitive dysfunctions and dementia [25]. Unfortunately, when PD motor signs emerge (preclinical phase) around $60-80 \%$ of dopaminergic neurons are lost, a fact that points out to the relevance of finding a biomarker of the pathology, especially for early stages of the disease when the motor signs are not apparent [26]. 
Glutamatergic neurotransmission within the basal ganglia circuitry is driven by cortical projections to the striatum -caudate and putamen in humans-, the subthalamic nucleus (STN) and the SNc; by thalamic projections to the cortex; and by STN afferents to the internal globus pallidus (GPi) and the substantia nigra pars reticulata (SNr) (Fig. 1). Inhibitory outputs (GABAergic) to the thalamocortical motor circuit are directed from the GPi and the SNr, where it acts to suppress movement. Accordingly, within the basal ganglia two major pathways exist and are referred to as the direct and indirect pathways (Fig. 1A and B). Interestingly, these two pathways are classically clasified acording to the dopamine receptor content of the GABAergic striatal medium spiny neurons (MSN) $[27,28]$. Thus, the direct pathway, which projects to the GPi/SNr (Fig. 1A), contains the neuropeptides dynorphin (DYN) and substance P (SP) and it express the dopamine $\mathrm{D}_{1}$ receptor $\left(D_{1} R\right)$ (Fig. 2). On the other hand, the indirect pathway, which projects to the globus pallidus pars externa (GPe) (Fig. 1B), contains the neuropeptide enkephaline (ENK) and express the dopamine $\mathrm{D}_{2}$ receptor $\left(\mathrm{D}_{2} \mathrm{R}\right)$ (Fig. 2). Regarding the normal functioning (non-pathological) of these structures, dopaminergic neurons from the SNc release dopamine into the putamen, which activates the direct pathway and inhibits the indirect pathway, and this results in a net inhibition of the GPi/SNr. Overall, this potentiates thalamocortical activity, which facilitates movements (Fig. 2), cognitive and behavioural outputs. Conversely, in PD, because of the loss of dopaminergic neurons in the SNc, striatal dopamine is reduced and the inhibition of the GPi/SNr decreases (Fig. 1C). As a consequence, an increment of the GABAergic activity coming from GPi and $\mathrm{SNr}$, the output nuclei of the basal ganglia (Fig. 1C), is observed and ends in both a reduction of the excitability of thalamic neurons and an alteration of their firing pattern $[29,30]$. On the other hand, the glutamatergic activity of the subthalamic projection neurons and the corticostriatal pathway is highly increased. Importantly, this last fact 
has lead to some interventional PD therapies aimed to drastically reduce this increased glutamatergic activity of the STN, for instance surgical ablation and functional inactivation through deep brain stimulation $[31,32]$. However, all surgical procedures have associated risks and surgery is not suitable for everyone (typically only for advanced PD refractory to pharmacotherapy). Therefore, common PD management is still mainly achieved by means of pharmacological treatments (i.e. L-DOPA), and given the tight interconnection between dopaminergic and glutamatergic neurotransmission established in the basal ganglia both in normal and in pathological conditions, the inclusion of other drugs (i.e. mGlu 5 blockers) targeting these systems is now under study and it is precisely the focus of this review.

mGlu $_{5}$ receptors are expressed throughout the whole basal ganglia, thus they can be found in the striatum (caudate nucleus and putamen), the globus pallidus, the substantia nigra, and the subthalamic nucleus (Fig. 2) [33]. Therefore, mGlu5 receptors may finetune the basal ganglia function by modulating virtually all synaptic contacts present in this group of interconnected subcortical nuclei. For instance, mGlu5 receptors modulate corticostriatal excitatory inputs to the basal ganglia, since they are located both in $D_{1} R$ and $\mathrm{D}_{2}$ R-containing striatal MSNs (Fig. 2), although because of this dichotomy in its striatal distribution it is difficult to predict the net effect of $\mathrm{mGlu}_{5}$ receptor activation/inhibition on the transmission of the direct and indirect pathways. In addition, mGlu5 receptors would modulate transmission through the direct (striatonigral) pathway because they are located in GPi and SNr neurons. Thus, it has been reported that receptor activation produced disinhibition of nigral output neurons by decreasing GABAergic inhibitory transmission [34]. Finally, mGlu5 receptors would also modulate transmission through the indirect pathway by its location at the striatopallidal, pallidosubthalamic and subthalamonigral synapses (Fig. 2) (for review see [33]). 
Collectively, these studies point out to a scenario in which mGlu5 receptor targeting within the basal ganglia will take place at different sites of action according to receptor's distribution, a fact that would potentially enhance the pharmacotherapy based on this type of receptors. Accordingly, it is feasible that the net effect of mGlu receptor $^{2}$ antagonists on basal ganglia motor function results from the overall receptor targeting at several different sites including the striatum, STN, and SNr neurons [33].

\section{MOLECULAR ASPECTS OF STRIATAL mGlu 5 RECEPTORS}

\section{$\mathrm{mGlu}_{5}$ receptor interacting proteins}

$\mathrm{mGlu}_{5}$ receptors belong to class $\mathrm{C}$ of $\mathrm{G}$ protein-coupled receptors (GPCRs) [35] and are composed of a ligand-binding domain linked through a cysteine-rich domain (CRD) to a typical seven transmembrane domain common to all GPCRs, followed by a C-terminal intracellular tail which is variable in length (see above) [6]. Interestingly, apart from of

the classical G-protein coupled signal cascades, $\mathrm{mGlu}_{5}$ receptors physically interact with a large variety of accessory proteins, which ensure the correct targeting and anchoring at synaptic specialization, thus increasing the diversity of receptor coupled signal cascades [36]. Thus, apart from of interacting with cytoskeletal (i.e. $\alpha$-actinin [37], and filamin-A [38]) and scaffold (i.e. CAL [39], Homer [40], NHERF-2 [41] and tamalin [42]) proteins, which impinge into the trafficking and anchoring of the receptor to specialized plasma membrane domains (i.e. synapses), $\mathrm{mGlu}_{5}$ receptors also interact with enzymes or proteins directly involved in intracellular signal pathways (i.e. CAIN [43], calmodulin [44], ephrin2B [45], NECAB2 [46], Norbin [47], optineurin [48], PKC [49], PP1 $\gamma$ [50] and Siah-1 [51]). In addition, since mGlu $_{5}$ receptors are plasma membrane proteins they also have the ability to laterally interact with other plasma membrane proteins, including GPCRs and ion channels. Indeed, mGlu ${ }_{5}$ receptors are 
able to form homo- and heteromers at the plasma membrane level $[52,53]$, and while receptor homodimers require the formation of a covalent disulphide bridge between the extracellular N-terminal domain [53] the heteromerization might involve the transmembrane domains [54]. mGlu $_{5}$ receptors may also heteromerize with other GPCRs belonging to a different receptor family (i.e. family A) such as the $\mu$-opioid receptor [55], the adenosine $A_{2 A}$ receptor $\left(A_{2 A} R\right)$ [56] and the $D_{2} R$ [57].

\section{Striatal $\mathrm{mGlu}_{5}$ receptor containing oligomers}

As described early, the striatum, the input nucleus of the basal ganglia [58], receives dopaminergic and glutamatergic afferents that converge in the dendritic spines of MSNs (for review see [59]) (Fig. 3). Thus, glutamatergic synapses are located at the head, while the dopaminergic afferents are usually located at the neck, of dendritic spines (Fig. 3). As a consequence, dopamine plays a major modulatory role into the excitatory effects of glutamate in the dendritic spines [60]. Importantly, in addition to dopamine and glutamate, the neuromodulator adenosine also plays a key role in the function of striatal GABAergic efferent neurons [61]. Interestingly, adenosine $\mathrm{A}_{2 \mathrm{~A}}$ receptors $\left(\mathrm{A}_{2 \mathrm{~A}} \mathrm{Rs}\right)$ are highly concentrated in the striatum, where by means of ultrastructural studies have been located at the dendritic spines of indirect pathway MSNs (i.e. the striatopallidal neurons), especially in the vicinity of glutamatergic synapses [62, 63], and thus presenting a very similar localization to that described for $\mathrm{mGlu}_{5}$ receptors [14] (Fig. 3). In fact, it has been reported that $A_{2 A}$ Rs functionally interact with $\mathrm{mGlu}_{5}$ receptors to modulate several downstream $\mathrm{mGlu}_{5}$ receptor-mediated effects (for review see [64]). Therefore, $A_{2 A} R$ and $m G l u$ receptor agonists and $A_{2 A} R$ and $m G l u_{5}$ receptor antagonists have been shown to produce synergistic effects at the behavioral level [6567]. Thus, these functional and morphological frameworks, together with the fact that it 
is well-established that $\mathrm{mGlu}_{5}$ receptors are able to form homo- and heteromers at the plasma membrane level $[52,53]$, supports the possible existence of a physical interaction between striatal $\mathrm{A}_{2 \mathrm{~A}} \mathrm{Rs}$ and $\mathrm{mGlu}_{5}$ receptors. Indeed, a $\mathrm{A}_{2 \mathrm{~A}} \mathrm{R}-\mathrm{mGlu}_{5}$ receptor interaction has been described both in heterologous expression systems and in native tissue, namely the striatum [56]. Interestingly, at this level the co-stimulation of both receptors leads to a synergistic effect on downstream signalling that may allow overriding the inhibitory tone imposed by endogenous dopamine acting at the $\mathrm{D}_{2} \mathrm{R}[56]$. Accordingly, it has also been considered the existence of oligomeric complexes that simultaneously contain adenosine, dopamine and glutamate receptors (e.g $\mathrm{A}_{2 \mathrm{~A}} \mathrm{R} / \mathrm{D}_{2} \mathrm{R} / \mathrm{mGlu}_{5}$ receptor) $[57,68]$ (Fig. 3). This oligomer would be located adjacent to the glutamatergic synapse of the dendritic spine of the ENK MSN, where the crosstalk within the receptor heteromers might help in theory to achieve a much more elaborated tuning in the regulation of both presynaptic and postsynaptic neuronal responses in the striatal local circuitry and to a proper performance of the striatal function [69-71] (Fig. 3). Overall, since these protein-protein interactions may play a key role in the mGlu $_{5}$ receptor-mediated control of glutamatergic neurotransmission they might be potentially involved in the pathophysiology of neurodegenerative and neuropsychiatric disorders, including addiction, depression, epilepsy, schizophrenia, Alzheimer's, Huntington's and Parkinson's disease [72], thus leading to consider oligomerization processes as new targets for the treatment of these pathologies.

\section{The rationale of blocking $\mathrm{mGlu}_{5}$ receptor in $\mathrm{PD}$}

As it has been previously commented, the management of PD still mainly consists of a pharmacological approach. Thus, the majority of these drug-based treatments look for restoring striatal dopamine signalling, in order to diminish the intensity of the occurring 
motor and non-motor symptoms. The most effective therapy for the management of this disease is therefore based on the use of drugs that mimic dopamine, initially the precursor L-DOPA (L-3,4-dihydroxyphenylalanine) [73] and later on other dopaminergic agents, which act to compensate for the loss of this neurotransmitter [74]. Interestingly, although L-DOPA and $\mathrm{D}_{2} \mathrm{R}$ agonists have been proved very efficacious in the management of PD symptoms, chronic treatment with these agents can result in a loss of efficacy and the appearance of motor (e.g. dyskinesia) and non-motor complications (e.g. psychosis and impulse-control disorders) [75]. Thus, as the disease progresses, smaller amount of dopamine neurons are available to store and release LDOPA-derived dopamine, and the patient's clinical status begins to fluctuate more and more, closely in accordance with the levels of L-DOPA in plasma. In addition, fluctuating L-DOPA-derived dopamine concentrations, in association with the disease progression, may be responsible for the development of motor fluctuations and dyskinesia (e.g. L-DOPA-induced diskynesia or LID).

It has been largely demonstrated that the pharmacological effects of mGlu receptor agonists and antagonists produced in some behavioural animal models parallels well with the effects observed after the treatment with $\mathrm{A}_{2 \mathrm{~A}} \mathrm{R}$ agonists and antagonists, respectively, specifically during the selective modulation of the $D_{2}$ R-mediated responses. Thus, $\mathrm{A}_{2 \mathrm{~A}} \mathrm{R}$ and $\mathrm{mGlu}_{5}$ receptor would synergize in the control of $\mathrm{D}_{2} \mathrm{R}$ mediated function, and it has been then postulated that this interaction would be instrumented by the feasible $\mathrm{A}_{2 \mathrm{~A}} \mathrm{R} / \mathrm{D}_{2} \mathrm{R} / \mathrm{mGlu}_{5}$ receptor oligomer located at the MSN (Fig. 3). In such way, upon $A_{2 A} R$ and mGlu$_{5}$ receptor co-stimulation, $\mathrm{D}_{2} \mathrm{R}$-mediated transmission has been shown to be blocked $[56,65,76]$, thus suggesting that the former oligomer (i.e. $\mathrm{A}_{2 \mathrm{~A}} \mathrm{R} / \mathrm{D}_{2} \mathrm{R} / \mathrm{mGlu}_{5}$ receptor) may play a key role on striatal neuronal function and dysfunction [56, 77-80]. Accordingly, it is well-accepted that a balanced 
glutamatergic, dopaminergic and adenosinergic neurotransmission is needed for proper striatal functioning, and that the $\mathrm{A}_{2 \mathrm{~A}} \mathrm{R} / \mathrm{D}_{2} \mathrm{R} / \mathrm{mGlu}_{5}$ receptor oligomer operates as a MSN integrative receptorial unit with an extraordinary degree of computation in sensing glutamate, dopamine and adenosine concentrations at the striatum (Fig. 3) [69, 70]. Overall, all this data provide a rationale for using $\mathrm{A}_{2 \mathrm{~A}} \mathrm{R}$ and $\mathrm{mGlu}_{5}$ receptor antagonists in PD [81, 82]. Furthermore, these non-dopaminergic-based PD therapies may also offer some advantages over dopamine medications, for instance by reducing side effects [83].

From the different promising PD treatments based on the indirect modulation of dopaminergic neurotransmission (for review see [83]), the use of $\mathrm{mGlu}_{5}$ receptor blockers has recently received considerable attention by the scientific community. Thus, preclinical data suggested that $\mathrm{mGlu}_{5}$ receptor blockers might not only be useful in PD treatment by potentiating the benefit of dopamine-based therapies but also by allowing drug dose lowering and by preventing LID development, which has precisely been associated to an increase of striatal glutamatergic neurotransmission [84]. Indeed, the use of PD animal models in preclinical studies has proved to be valuable experimental tools to assess the efficacy of $\mathrm{mGlu}_{5}$ receptor-based drugs on both reversing motor symptoms and slowing the associated progressive neurodegeneration. Genetic PD animal models based on specific mutations of genes observed in PD familial cases (e.g. alterations in parkin, $\alpha$-synuclein, leucine-rich repeat kinase 2 (LRRK2), phosphatase and tensin homolog (PTEN)-induced putative kinase 1 (PINK1) and Parkinson disease autosomal recessive, early onset- 7 (PARK7)) [85] have been shown to be useful for the study of the pathogenesis of familial PD, although since these animal models do not recreate some characteristics of the human disease (e.g. severe motor deficits, lack of dopaminergic neurons degeneration, etc.) they are experimentally restricted to disease 
associated molecular and cellular studies and often inadequate to pharmacotherapy studies [86]. Accordingly, the preclinical evaluation of $\mathrm{mGlu}_{5}$ receptor-based drugs have largely relied on pharmacological and toxin-based animal models of PD because these last models often replicate specific pathogenic events and behavioral outcomes of PD. The neurotoxic PD animal models based on systemic or intracerebral administration of compounds that produce both reversible (i.e. haloperidol and reserpine) and irreversible (i.e. 1-methyl-4-phenyl-1,2,3,6-tetrahydropyridine (MPTP), 6-hydroxydopamine (6-OHDA), paraquat and rotenone) parkinsonian effects have been effectively used in PD pharmacotherapy studies. Indeed, since the irreversible toxinbased models of PD recapitulate the morphological aspects of the disease (i.e. dopaminergic system degeneration), and also produce a PD-related pathology and symptomatology, they constitute golden standards models in the study of the diseasemodifying potential of the mGlu5 receptor-based drugs.

The 6-OHDA is a classic and widespread toxin-based animal model of PD [87] that has been successfully used in the study of the function of the mGlu $_{5}$ receptor in PD. Partial bilateral 6-OHDA lesions cause akinetic deficits in reaction time tasks, thus recreating a parkinsonian effect of the earlier stages of the disease. Interestingly, it was demonstrated that the chronic instead the acute treatment with 2-methyl-6(phenylethynyl)-pyridine (MPEP), a mGlu 5 receptor antagonist, reversed these akinetic deficits [88, 89], therefore suggesting that MPEP treatment might alleviate PDassociated motor executive deficits in an operant task. Also, the effects of MPEP on parkinsonian cognitive deficits has been studied and thus demonstrated that MPEP, either acutely or subchronically, antagonized the visuo-spatial discrimination deficit induced by bilateral 6-OHDA lesion of the striatum [90]. Moreover, in partially lesioned rats chronic systemic MPEP treatment was shown to be neuroprotective and to 
reverse the abnormal firing activity of dopaminergic neurons [91]. Interestingly, in addition to the MPEP-mediated cognitive and behavioural effects, the same treatment also increased contralateral turning induced by L-DOPA in mice bearing unilateral 6OHDA lesion [90], thus confirming the therapeutic potential of $\mathrm{mGlu}_{5}$ receptor blockade on motor symptoms produced by reduced striatal dopaminergic transmission (for review see [92]). On the other hand, the MPTP animal model of PD, mainly used in nonhuman primates and mice (rats are resistant to MPTP) [93], also seed some light about the potential therapeutic usage of $\mathrm{mGlu}_{5}$ receptor antagonists in PD. Interestingly, an upregulation of $\mathrm{mGlu}_{5}$ receptors in the posterior putamen and pallidum of MPTPtreated monkeys has been associated with LID development in this PD animal model [94], thus also supporting that $\mathrm{mGlu}_{5}$ receptor blockade might alleviate LIDs. Indeed, reduction of glutamatergic neurotransmission by selective $\mathrm{mGlu}_{5}$ receptor noncompetitive antagonists, either MPEP or 3-((2-methyl-1,3-thiazol-4-yl)ethynyl)pyridine (MTEP), has been shown to improve locomotion and alleviate LID in PD animal models [95-97]. Needless to say, apart from the $\mathrm{mGlu}_{5}$ receptor blockers we revise here, other agents able to reduce glutamate neurotransmission might indeed become valued drugs to PD therapy. Thus, amantadine, an NMDA-receptor antagonist, has demonstrated efficacy in reducing LID both in animal models and PD patients, although its short-term efficacy, together with its neurological side effects, has precluded its clinical use $[98,99]$. Overall, the antidyskinetic efficacy of selective mGlu $_{5}$ receptor antagonists supports the hypothesis that abnormally increased glutamatergic neurotransmission is involved in LID and points to the mGlu $_{5}$ receptor as a potential therapeutic target for the treatment of LID. Collectively, these preclinical studies supported the use of $\mathrm{mGlu}_{5}$ receptor antagonists as anti-parkinsonian drugs. 


\section{CLINICAL EVALUATION OF mGlu 5 RECEPTOR BLOCKERS IN PD}

In clinics, the therapeutic potential of $\mathrm{mGlu}_{5}$ receptors has been progressively explored, mainly for both peripheral and central nervous disorders ranging from psychiatric, neurological to neuromuscular illnesses [100]. Indeed, the usefulness of mGlu receptor blockers is actually being challenged not only in neurodegenerative disorders as PD but also in the treatment of addiction, pain, schizophrenia or anxiety disorders [101, 102]. Regarding the management of PD, these kind of compounds has been mainly proposed as adjuvant drugs to PD L-DOPA therapy, not only as a feasible option assisting the symptomatic PD treatment but mostly for the alleviation of LID [92]. Indeed, several negative allosteric modulators of $\mathrm{mGlu}_{5}$ receptors have been reported, with multiple compounds in preclinical or clinical development, such as fenobam (NP-2009), raseglurant (ADX10059), diplagurant (ADX48621), AFQ056 and others [103]. Nevertheless, it is also true that still few clinical trials assessing the efficacy of these compounds in human beings have been carried out (Table 1) or are ongoing (Table 2). From this plethora of compounds, it is worth mentioning the drug (3aR,4S,7aR)Octahydro-4-hydroxy-4-[(3-methylphenyl)ethynyl]-1H-indole-1-carboxylic acid methyl ester, named AFQ056 (Novartis Pharma AG, Basel, Switzerland), which is a potent selective negative allosteric modulator of the $\mathrm{mGlu}_{5}$ receptor, and that has been evaluated in animal models as well as in PD clinical trials, but also in other indications such as the fragile $\mathrm{X}$ syndrome $[104,105]$, nicotine addiction ([106] and gastrooesophageal reflux disease [107]. The clinical efficacy and safety of AFQ056 has been evaluated in a few number of double-blind, placebo-controlled randomised clinical trials involving patients with moderate to severe L-DOPA induced dyskinesias in PD (Novartis Clinical Trial Results Database: 
le.do?trialResult=3129; CAFQ056A2206,http://www.novctrd.com/ctrdWebApp/clinicalt rialrepository/displayFile.do?trialResult=3402

CAFQ606A2208,http://www.novctrd.com/ctrdWebApp/clinicaltrialrepository/displayFi $\underline{\text { le.do?trialResult }=4745} \quad[109] \quad$ and $\quad$ CAFQ056A2216, http://www.novctrd.com/ctrdWebApp/clinicaltrialrepository/displayFile.do?trialResult= 6483 [110]) (Table 1). Importantly, only the complete results of two of the clinical trials have been published [108], while the others just presented in international congresses $[109,110]$. The primary objectives of these trials were to assess the antidyskinetic efficacy, as well as the safety and tolerability, of multiple AFQ056 doses on moderate to severe LID in PD patients. Interestingly, a low number (less than 300) of patients have been currently included in these clinical trials, whose main characteristics are shown in table 3. In brief, the mean age (SD) of the patients in these trials was 64.5 (8.6) years old and approximately 53\% were men. On the other hand, for the inclusion of these patients in the named clinical trials they had to have received L-DOPA for at least 3 years and were required to remain on stable L-DOPA therapy for the duration of these studies. Moreover, these patients were also required to have moderate to severe LID. Finally, it is also worth to mention that these studies were short in time (from two to twelve weeks) (Table 1).

Regarding the dose of AFQ056 used, in two clinical trials it was steadily increased every 4 days from $25 \mathrm{mg}$ to a maximum dose of $150 \mathrm{mg}$ twice a day during a period of 16 days (CAFQ056A2203 and CAFQ056A2206), and just in one of them patients were also down-titrated (50 mg twice a day) from day 17 to day $20 \mathrm{mg}$ (CAFQ056A2206) [108]. Thus, in the studies carried out by Berg et al. [108] the mean dose received was of 103.57 and $111.70 \mathrm{mg}$ twice a day in study 1 (CAFQ056A2203) and study 2 (CAFQ056A2206), respectively. Conversely, Stocchi et al. compared different multiple 
fixed-doses of AFQ056 (10, 25, 50, 75 and $100 \mathrm{mg}$ twice a day; CAFQ606A2208) [109]. Finally, in the study performed by Kumar et al., AFQ056 was up-titrated during a two-week period treatment from $25 \mathrm{mg}$ twice a day to $100 \mathrm{mg}$ twice a day, when LDOPA was kept stable for a week and then it started a a three-week period in which the L-DOPA dose was increased. Finally, during the taper-off period both AFQ056 and LDOPA were gradually down titrated to the initial doses used during the run-in phase (CAFQ056A2216) [110].

Concerning the primary outcome measured in the different clinical trials it consisted of assessing the anti-dyskinetic efficacy. Accordingly, different scales were used, such as Lang-Fanh Activities of Daily Living Dyskinesia Scale (LFADLDS) and modified Abnormal Involuntary Movement Scale (AIMS), as well as motor function using Unified Parkinson's Disease Rating Scale (UPDRS) part III. Other secondary assessments of the anti-dyskinetic AFQ056 effects were done by means of other scales, such as UPDRS part IV (items 32-33) and Parkinson Disease Dyskinesia (PDYS-26). However, several methodological problems arise from using these PD scales to measure dyskinesia, which have been well described elsewhere [111]. For instance, as mentioned above, the short duration of these clinical trials, or importantly the lack of a fully validation of some scales (i.e. LFADLDS and the modified AIMS version), which may have limited the ability to detect changes in functional impairment among the study population. Therefore, although AFQ056 showed some antidyskinetic efficacy when measuring dyskinesia with the former scales, the clinical relevance of these results can be considered is vague and difficult to interpret (Table 4). Thus, no significant effects were seen on UPDRS-III in any study. Similarly, only in the Stocchi et al. study (CAFQ606A2208) [109] there was a dose-response relationship in the primary outcome (change from baseline at week 12 on the modified AIMS) with the $100 \mathrm{mg}$ twice-a-day 
dose (Table 5). And again, no significant changes were observed in any case on the secondary outcomes, such as Parkinson Disease Dyskinesia Scale (PDYS-26), Clinical Global Impression of Change (CGIC) and UPDRS-III.

With respect to possible adverse effects of the studied drug, summing the total number of adverse events observed in the abovementioned four clinical trials, they were found in 128 patients out of $169(75.7 \%)$ treated with AFQ056 and in 70 patients out of 100 (70\%) treated with placebo. The reported adverse events were typically mild to moderate in severity and included nervous system, gastrointestinal and psychiatric disorders (Table 6). Dizziness (15\%) and dyskinesia (7\%), followed by nausea (4\%) and hallucinations $(4 \%)$ were the most common adverse events in patients treated with AFQ056 (Table 6) while dyskinesia (18\%) and nausea (8\%) were the most frequent in patients treated with placebo. Importantly, twenty patients out of 169 patients treated with AFQ056 (11.8\%) discontinued the experimental drug as a consequence of adverse events appearance. Concretely, in the two clinical trials carried out by Berg et al. (CAFQ056A2203 and CAFQ056A2206) [108], the most common severe adverse event was worsening of dyskinesia, which arose after stopping treatment. Thus, five severe adverse events were observed in the study 1 of Berg et al. (CAFQ056A2203), from which four occurred in the AFQ056 group and were considered serious (two patients experienced worsening of dyskinesia, one patient developed hyperkinesia, and one patient had two serious events, such as a fall and rhabdomyolisis). Similarly, in the study 2 of Berg et al. (CAFQ056A2206) there were four severe adverse events in the AFQ056 group and three in the placebo group, from which two in each group were considered serious adverse events. Noteworthy, and related to the results obtained in the study 1, two serious adverse events in AFQ056-treated patients were suspected to be related to the study medication. In particular, one patient developed psychosis, which 
required discontinuation of treatment, while the other patient had dyskinesia worsening. In the Stocchi et al. study (CAFQ606A2208) [109], adverse events were reported by $65.1 \%$ of the placebo group patients and by $75 \%$ of the medication study group of patients daily-treated with $100 \mathrm{mg}$ of AFQ056. Importantly, adverse events requiring dosing modification or interruption increased progressively from $4.8 \%$ in the placebo group to $22.7 \%$ in the AFQ056 (200 mg/daily) group. Finally, serious adverse events were observed in $9.5 \%$ of the placebo group and in $11.4 \%$ of AFQ056 $200 \mathrm{mg} /$ dailytreated patients. In such way, psychosis and psychotic disorders-related adverse events increased gradually from $1.6 \%$ in the placebo group to $22.7 \%$ in the AFQ056 (200 $\mathrm{mg}$ /daily) group of patients.

To finish with the AFQ056 characterization, it is needed to say that scarce information is available about AFQ056 pharmacokinetics. Thus, it has been shown that the steady state plasma concentration-time profiles of AFQ056 alone or when co-administered with L-DOPA/carbidopa are similar, thus indicating that the co-administration of a LDOPA/carbidopa combination has no relevant effects on AFQ056 pharmacokinetics [112]. On the other hand, the pharmacokinetics of AFQ056 has been shown to be altered in subjects with renal impairmen: the AUC (area under the plasma concentration-time curve) of AFQ506 is increased in patients with mild, moderate and severe renal impairment, compared with healthy control subjects (Novartis Clinical Trial Database:

CAFQ056A2124, http://www.novctrd.com/ctrdWebApp/clinicaltrialrepository/displayFile.do?trialResult= 6624). Finally, no data is available assessing the pharmacokinetics of AFQ056 in subjects with hepatic impairment, although some studies are now ongoing.

In summary, despite the promising results observed in preclinical studies, today there are few clinical trials, including a small number of PD patients, which have assessed the 


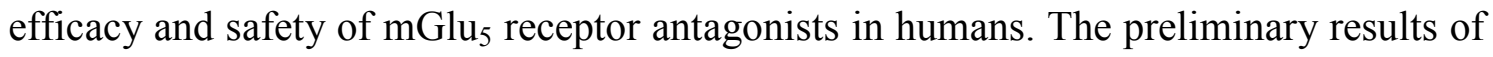
these studies suggest some antidyskinetic efficacy in PD patients with LID, but the clinical relevance of the reported outcomes is uncertain and difficult to interpret due to the methodological problems associated with the measuring-scales used. On the other hand, adverse events (from mild to moderate in severity) associated with these drugs have been shown to be common (mainly gastrointestinal and neuropsychiatric disorders), and together with the fact that there is still lacking consistent pharmacokinetic data to establish the optimum drug-treatment, it is obvious that more research is needed to properly evaluate the therapeutic potential of this new group of drugs in the treatment of PD.

\section{CONCLUDING REMARKS}

The current pharmacological approach dealing with parkinsonian symptoms entirely relies on dopamine replacement therapy either with L-DOPA or with $\mathrm{D}_{2} \mathrm{R}$ agonists. However, long-term dopamine-based therapies promote the development of intolerable motor adverse effects like dyskinesia and motor fluctuations. As a consequence, a lot of effort has been focused on the search for new non-dopaminergic-based drugs to be incorporated into PD therapeutic arsenal. Indeed, $\mathrm{mGlu}_{5}$ receptor blockers constitute one of the most attractive non-dopaminergic classes of drugs for PD management in general and for the LID treatment in particular. Accordingly, these drugs would have antiparkinsonian effects by reducing the excitatory drive occurring in the enkephalin MSN of the overactive parkinsonian basal ganglia, a phenomenon that might be related to the physical interaction (oligomerization) between $\mathrm{D}_{2} \mathrm{R}$ and $\mathrm{mGlu}_{5}$ receptor in the MSN glutamatergic synapses. 


\section{ACKNOWLEDGMENTS}

This work was supported by grants SAF2011-24779 and Consolider-Ingenio CSD200800005 from "Ministerio de Economia y Competitividad" (MINECO) and ICREA Academia-2010 from the Catalan Institution for Research and Advanced Studies to FC. The authors belong to the "Neuropharmacology and Pain" accredited research group (Generalitat de Catalunya, 2009 SGR 232).
ABBREVIATIONS
$\mathrm{AD} \quad=\quad$ Alzheimer`s disease
$\mathrm{A}_{2 \mathrm{~A}} \mathrm{R}=$ adenosine $\mathrm{A}_{2 \mathrm{~A}}$ receptor
AMPA $=\alpha$-amino-3-hydroxy-5-methyl-4-isoxazolepropionic acid
CNS $=$ central nervous system
$\mathrm{D}_{1} \mathrm{R}=$ dopamine $\mathrm{D}_{1}$ receptor
$\mathrm{D}_{2} \mathrm{R}=$ dopamine $\mathrm{D}_{2}$ receptor
$\mathrm{DYN} \quad=\quad$ dynorphin
ENK $=$ enkephalin
GABA $=\gamma$-aminobutyric acid
Glu $\quad=\quad$ L-glutamate
GPCR $=$ G protein-coupled receptor
$\mathrm{GPe}=\quad$ globus pallidus pars externa
$\mathrm{GPi}=\quad$ globus pallidus pars interna
6-OHDA $=$ 6-hydroxydopamine
LC $=$ locus coeruleus
L-DOPA = L-3,4-dihydroxyphenylalanine
LRRK2 = leucine-rich repeat kinase 2 


\begin{tabular}{|c|c|c|}
\hline iGlu & $=$ & ionotropic glutamate \\
\hline LID & $=$ & L-DOPA induced dyskinesias \\
\hline mGlu & $=$ & metabotropic glutamate \\
\hline MPEP & $=$ & 2-methyl-6-(phenylethynyl)pyridine \\
\hline МPTP & $=$ & 1-methyl-4-phenyl-1,2,3,6-tetrahydropyridine \\
\hline MSN & $=$ & GABAergic medium spiny neurons \\
\hline MTEP & $=$ & 3-((2-methyl-1,3-thiazol-4-yl)ethynyl)pyridine \\
\hline NMDA & $=$ & N-methyl-D-aspartic acid \\
\hline PARK7 & $=$ & Parkinson disease (autosomal recessive, early onset) 7 \\
\hline PD & $=$ & Parkinson's disease \\
\hline PINK1 & $=$ & PTEN-induced putative kinase 1 \\
\hline PTEN & $=$ & phosphatase and tensin homolog \\
\hline $\mathrm{SNc}$ & $=$ & substantia nigra pars compacta \\
\hline $\mathrm{SNr}$ & $=$ & substantia nigra pars reticulata \\
\hline STN & $=$ & subthalamic nucleus \\
\hline UPDRS & $=$ & Unified Parkinson's Disease Rating Scale \\
\hline
\end{tabular}




\section{FIGURE LEGENDS}

Fig. 1. Scheme of the basal ganglia circuitry and its connection to the thalamocortical circuit in both normal and PD conditions. Dopaminergic neurons from the substantia nigra pars compacta ( $\mathrm{SNc}$, shown in black punctate) control the direct (A) and indirect (B) pathways within the basal ganglia via activation of $D_{1} R$ or $\mathrm{D}_{2} \mathrm{R}$. Thus, the striatum, which in humans comprises the caudate and putamen, is linked to the complex formed by the substantia nigra pars reticulata $(\mathrm{SNr})$ and the globus pallidus pars interna (GPi) via direct (striatonigral) and indirect (striatal-pallidalsubthalamic-nigral) pathways. Accordingly, within the direct pathway (A) GABAergic projections (red arrows) inhibit the functioning of the basal ganglia output nuclei, the SNr-GPi complex. The SNr-GPi complex sends inhibitory projections (GABAergic; red arrows) to the thalamus, which in turn regulates excitatory output to the cortex (glutamatergic; green arrows). Dopaminergic neurons (blue arrows) from the substantia nigra pars compacta (SNc) project to medium spiny neurons (MSN) of the putamen which express $D_{1} R$, thus stimulating transmission through the direct pathway. On the other hand, within the indirect pathway (B) GABAergic projections (red arrows) from the putamen project to the globus pallidus pars externa (GPe), which in turn project inhibitory projections (GABAergic; red arrows) to the GPi and subthalamic nucleus (STN). SNc dopaminergic neurons (blue arrows) project to putamen MSNs expressing $\mathrm{D}_{2} \mathrm{R}$ which thus reduce the activity of the indirect direct pathway. In addition, STN send excitatory (glutamatergic; green arrows) projections to the SNr-GPi complex, thus balancing the inhibitory tone mediated by the direct pathway and the level of inhibition of the thalamus, which modulates excitation of the motor areas of the cortex. In PD (C) there is a loss of SNc dopaminergic neurons which results in a reduction in the direct pathway-mediated inhibitory transmission and an increase in the indirect pathway- 
mediated inhibitory transmission, therefore resulting in an increased excitation of the output nuclei via the STN. Overall, this increase in the excitation of the SNr-GPi complex implies a concomitant increase of GABAergic tone at the thalamus which ends with a reduction of the excitation of cortical motor areas. Adapted from [92] and [113].

Fig. 2. Localization of dopamine, adenosine and metabotropic glutamate receptors within the basal ganglia circuitry. The dopamine, adenosine and metabotropic glutamate receptors with interest to PD therapy are depicted in a scheme showing the direct and indirect basal ganglia pathaways (see Fig. 1A and B). The co-distribution of $\mathrm{D}_{2} \mathrm{R}, \mathrm{A}_{2 \mathrm{~A}} \mathrm{R}$ and $\mathrm{mGlu}_{5}$ receptor within the same striatal neurons, namely the enkephalinergic medium spiny neuron, puts into significance the potential role of oligomers formed by these GPCRs and postulates the use of striatal $\mathrm{mGlu}_{5}$ receptors as therapeutic targets in PD. SNc: substantia nigra pars compacta; SNr: substantia nigra pars reticulata; GPi: globus pallidus pars interna; GPe: globus pallidus pars externa; STN: subthalamic nucleus; ENK: enkephalinergic neuron; DYN: dynorphinergic neuron. Adapted from [81].

Fig. 3. Schematic representation of a striatal GABAergic enkefalinergic neuron dendritic spine containing dopamine, adenosine and metabotropic glutamate receptors. The subcellular distribution of $A_{2 A} R, D_{2} R$ and $m G l u_{5}$ receptor in rat striatum is shown (left panel). Electron micrograph showing immunoreactivity for $A_{2 A} R, D_{2} R$ and $\mathrm{mGlu}_{5}$ receptor in rat striatum as revealed using a triple-labeling post-embedding immunogold technique. Immunoparticles for $A_{2 A} R\left(10 \mathrm{~nm}\right.$ size, arrows), $D_{2} R(15 \mathrm{~nm}$ size, crossed arrows) and $\mathrm{mGlu}_{5}$ receptor (20 $\mathrm{nm}$ size, arrowheads) were detected along the extrasynaptic and perisynaptic plasma membrane of the same dendritic spine (s) establishing excitatory synaptic contact with axon terminals. Adapted from Ref. [57]. 
Schematic representation of a striatal GABAergic enkefalinergic neuron dendritic spine (right panel). The $\mathrm{A}_{2 \mathrm{~A}} \mathrm{R} / \mathrm{D}_{2} \mathrm{R} / \mathrm{mGlu}_{5}$ receptor oligomer shows a perisynaptic and extrasynaptic distribution within the dendritic spine of the enkephalin MSNs and controls the excitability of these neurons. Interestingly, under weak glutamatergic neurotransmission $\mathrm{D}_{2} \mathrm{R}$ activation, apart from inhibiting adenylyl-cyclase, it enhances phospholipase $\mathrm{C}$ (PLC) function, which activates protein-phosphatase2B (PP-2B or calcineurin), which in turns inactivates L-type voltage-dependent calcium channels (Ltype VDCCs). This is the main mechanism involved in the $\mathrm{D}_{2} \mathrm{R}$-mediated suppression of activity in the striatopallidal neuron [114]. Accordingly, under weak glutamatergic neurotransmission $\mathrm{D}_{2} \mathrm{R}$ functioning predominates and a decrease in neuronal excitability is observed. However, under conditions of strong glutamatergic neurotransmission, which is associated with adenosine release, there is a robust stimulation of both $\mathrm{A}_{2 \mathrm{~A}} \mathrm{R}$ and $\mathrm{mGlu}_{5}$ receptor. The $\mathrm{A}_{2 \mathrm{~A}} \mathrm{R}$ and $\mathrm{mGlu}_{5}$ receptor, through an oligomeric interaction, preclude $\mathrm{D}_{2} \mathrm{R}$ functioning and thus favours neuronal excitability. In green and red, stimulatory and inhibitory effects, respectively are shown. AMPAR: AMPA receptor. NMDAR: NMDA receptor. Adapted from [115]. 


\section{REFERENCES}

[1] Meldrum, B.S. Glutamate as a neurotransmitter in the brain: Review of physiology and pathology. J. Nutr., 2000, 130, 1007S-15S.

[2] Robinson, M.B.; Coyle, J.T. Glutamate and related acidic excitatory neurotransmitters: From basic science to clinical application. FASEB J., 1987, $1,446-455$.

[3] Lau, A.; Tymianski, M. Glutamate receptors, neurotoxicity and neurodegeneration. Pflugers Arch., 2010, 460, 525-542.

[4] Coyle, J.T.; Puttfarcken, P. Oxidative stress, glutamate, and neurodegenerative disorders. Science, 1993, 262, 689-695.

[5] Traynelis, S.F.; Wollmuth, L.P.; McBain, C.J.; Menniti, F.S.; Vance, K.M.; Ogden, K.K.; Hansen, K.B.; Yuan, H.; Myers, S.J.; Dingledine, R. Glutamate receptor ion channels: Structure, regulation, and function. Pharmacol. Rev., 2010, 62, 405-496.

[6] Pin, J.P.; Duvoisin, R. The metabotropic glutamate receptors: Structure and functions. Neuropharmacology, 1995, 34, 1-26.

[7] Hollmann, M.; Heinemann, S. Cloned glutamate receptors. Annu. Rev. Neurosci., 1994, 17, 31-108.

[8] Ferraguti, F.; Crepaldi, L.; Nicoletti, F. Metabotropic glutamate 1 receptor: Current concepts and perspectives. Pharmacol. Rev., 2008, 60, 536-581.

[9] Pin, J.P.; Waeber, C.; Prezeau, L.; Bockaert, J.; Heinemann, S.F. Alternative splicing generates metabotropic glutamate receptors inducing different patterns of calcium release in xenopus oocytes. Proc. Natl. Acad. Sci. U. S. A., 1992, 89, 10331-10335. 
[10] Grandes, P.; Mateos, J.M.; Ruegg, D.; Kuhn, R.; Knopfel, T. Differential cellular localization of three splice variants of the mGluR1 metabotropic glutamate receptor in rat cerebellum. Neuroreport, 1994, 5, 2249-2252.

[11] Romano, C.; Smout, S.; Miller, J.K.; O'Malley, K.L. Developmental regulation of metabotropic glutamate receptor $5 \mathrm{~b}$ protein in rodent brain. Neuroscience, 2002, 111, 693-698.

[12] Corti, C.; Clarkson, R.W.; Crepaldi, L.; Sala, C.F.; Xuereb, J.H.; Ferraguti, F. Gene structure of the human metabotropic glutamate receptor 5 and functional analysis of its multiple promoters in neuroblastoma and astroglioma cells. $J$. Biol. Chem., 2003, 278, 33105-33119.

[13] Romano, C.; Sesma, M.A.; McDonald, C.T.; O'Malley, K.; Van den Pol, A.N.; Olney, J.W. Distribution of metabotropic glutamate receptor mGluR5 immunoreactivity in rat brain. J. Comp. Neurol., 1995, 355, 455-469.

[14] Lujan, R.; Nusser, Z.; Roberts, J.D.; Shigemoto, R.; Somogyi, P. Perisynaptic location of metabotropic glutamate receptors mGluR1 and mGluR5 on dendrites and dendritic spines in the rat hippocampus. Eur. J. Neurosci., 1996, $8,1488-1500$.

[15] Mannaioni, G.; Marino, M.J.; Valenti, O.; Traynelis, S.F.; Conn, P.J. Metabotropic glutamate receptors 1 and 5 differentially regulate CA1 pyramidal cell function. J. Neurosci., 2001, 21, 5925-5934.

[16] Musante, V.; Neri, E.; Feligioni, M.; Puliti, A.; Pedrazzi, M.; Conti, V.; Usai, C.; Diaspro, A.; Ravazzolo, R.; Henley, J.M.; Battaglia, G.; Pittaluga, A. Presynaptic mGlu1 and mGlu5 autoreceptors facilitate glutamate exocytosis from mouse cortical nerve endings. Neuropharmacology, 2008, 55, 474-482. 
[17] Gubellini, P.; Pisani, A.; Centonze, D.; Bernardi, G.; Calabresi, P. Metabotropic glutamate receptors and striatal synaptic plasticity: Implications for neurological diseases. Prog. Neurobiol., 2004, 74, 271-300.

[18] Conquet, F.; Bashir, Z.I.; Davies, C.H.; Daniel, H.; Ferraguti, F.; Bordi, F.; Franz-Bacon, K.; Reggiani, A.; Matarese, V.; Conde, F. Motor deficit and impairment of synaptic plasticity in mice lacking mGluR1. Nature, 1994, 372, 237-243.

[19] Gubellini, P.; Saulle, E.; Centonze, D.; Bonsi, P.; Pisani, A.; Bernardi, G.; Conquet, F.; Calabresi, P. Selective involvement of mGlu1 receptors in corticostriatal LTD. Neuropharmacology, 2001, 40, 839-846.

[20] Sung, K.W.; Choi, S.; Lovinger, D.M. Activation of group I mGluRs is necessary for induction of long-term depression at striatal synapses. $J$. Neurophysiol., 2001, 86, 2405-2412.

[21] Bonsi, P.; Pisani, A.; Bernardi, G.; Calabresi, P. Stimulus frequency, calcium levels and striatal synaptic plasticity. Neuroreport, 2003, 14, 419-422.

[22] Gubellini, P.; Saulle, E.; Centonze, D.; Costa, C.; Tropepi, D.; Bernardi, G.; Conquet, F.; Calabresi, P. Corticostriatal LTP requires combined mGluR1 and mGluR5 activation. Neuropharmacology, 2003, 44, 8-16.

[23] Lang, A.E.; Lozano, A.M. Parkinson's disease. first of two parts. N. Engl. J. Med., 1998, 339, 1044-1053.

[24] Poewe, W.; Mahlknecht, P. The clinical progression of parkinson's disease. Parkinsonism Relat. Disord., 2009, 15 Suppl 4, S28-32.

[25] Hely, M.A.; Morris, J.G.; Reid, W.G.; Trafficante, R. Sydney multicenter study of parkinson's disease: Non-L-dopa-responsive problems dominate at 15 years. Mov. Disord., 2005, 20, 190-199. 
[26] Meissner, W.G.; Frasier, M.; Gasser, T.; Goetz, C.G.; Lozano, A.; Piccini, P.; Obeso, J.A.; Rascol, O.; Schapira, A.; Voon, V.; Weiner, D.M.; Tison, F.; Bezard, E. Priorities in parkinson's disease research. Nat. Rev. Drug Discov., 2011, 10, 377-393.

[27] Reiner, A.; Medina, L.; Haber, S.N. The distribution of dynorphinergic terminals in striatal target regions in comparison to the distribution of substance P-containing and enkephalinergic terminals in monkeys and humans. Neuroscience, 1999, 88, 775-793.

[28] Steiner, H.; Gerfen, C.R. Role of dynorphin and enkephalin in the regulation of striatal output pathways and behavior. Exp. Brain Res., 1998, 123, 60-76.

[29] Ceballos-Baumann, A.O.; Obeso, J.A.; Vitek, J.L.; Delong, M.R.; Bakay, R.; Linazasoro, G.; Brooks, D.J. Restoration of thalamocortical activity after posteroventral pallidotomy in parkinson's disease. Lancet, 1994, 344, 814.

[30] Vitek, J.L.; Ashe, J.; DeLong, M.R.; Alexander, G.E. Physiologic properties and somatotopic organization of the primate motor thalamus. J. Neurophysiol., 1994, 71, 1498-1513.

[31] Betchen, S.A.; Kaplitt, M. Future and current surgical therapies in parkinson's disease. Curr. Opin. Neurol., 2003, 16, 487-493.

[32] Limousin, P.; Martinez-Torres, I. Deep brain stimulation for parkinson's disease. Neurotherapeutics, 2008, 5, 309-319.

[33] Rouse, S.T.; Marino, M.J.; Bradley, S.R.; Awad, H.; Wittmann, M.; Conn, P.J. Distribution and roles of metabotropic glutamate receptors in the basal ganglia motor circuit: Implications for treatment of parkinson's disease and related disorders. Pharmacol. Ther., 2000, 88, 427-435. 
[34] Wittmann, M.; Marino, M.J.; Bradley, S.R.; Conn, P.J. GABAergic inhibition of substantia nigra pars reticulata projection neurons is modulated by metabotropic glutamate receptors. Soc Neurosci Abstr, 1999, 25 , 446.

[35] Fredriksson, R.; Lagerstrom, M.C.; Lundin, L.G.; Schioth, H.B. The G-proteincoupled receptors in the human genome form five main families. phylogenetic analysis, paralogon groups, and fingerprints. Mol. Pharmacol., 2003, 63, 12561272.

[36] Enz, R. Metabotropic glutamate receptors and interacting proteins: Evolving drug targets. Curr. Drug Targets, 2012, 13, 145-156.

[37] Cabello, N.; Remelli, R.; Canela, L.; Soriguera, A.; Mallol, J.; Canela, E.I.; Robbins, M.J.; Lluis, C.; Franco, R.; Mcllhinney, R.A.; Ciruela, F. Actinbinding protein alpha-actinin-1 interacts with the metabotropic glutamate receptor type $5 \mathrm{~b}$ and modulates the cell surface expression and function of the receptor. J. Biol. Chem., 2007, 282, 12143-12153.

[38] Enz, R. The actin-binding protein filamin-A interacts with the metabotropic glutamate receptor type 7. FEBS Lett., 2002, 514, 184-188.

[39] Cheng, S.; Zhang, J.; Zhu, P.; Ma, Y.; Xiong, Y.; Sun, L.; Xu, J.; Zhang, H.; He, J. The PDZ domain protein CAL interacts with mGluR5a and modulates receptor expression. J. Neurochem., 2010, 112, 588-598.

[40] Tu, J.C.; Xiao, B.; Yuan, J.P.; Lanahan, A.A.; Leoffert, K.; Li, M.; Linden, D.J.; Worley, P.F. Homer binds a novel proline-rich motif and links group 1 metabotropic glutamate receptors with IP3 receptors. Neuron, 1998, 21, 717726. 
[41] Paquet, M.; Asay, M.J.; Fam, S.R.; Inuzuka, H.; Castleberry, A.M.; Oller, H.; Smith, Y.; Yun, C.C.; Traynelis, S.F.; Hall, R.A. The PDZ scaffold NHERF-2 interacts with mGluR5 and regulates receptor activity. J. Biol. Chem., 2006, 281, 29949-29961.

[42] Kitano, J.; Kimura, K.; Yamazaki, Y.; Soda, T.; Shigemoto, R.; Nakajima, Y.; Nakanishi, S. Tamalin, a PDZ domain-containing protein, links a protein complex formation of group 1 metabotropic glutamate receptors and the guanine nucleotide exchange factor cytohesins. J. Neurosci., 2002, 22, 12801289.

[43] Ferreira, L.T.; Dale, L.B.; Ribeiro, F.M.; Babwah, A.V.; Pampillo, M.; Ferguson, S.S. Calcineurin inhibitor protein (CAIN) attenuates group I metabotropic glutamate receptor endocytosis and signaling. J. Biol. Chem., 2009, 284, 28986-28994.

[44] Minakami, R.; Jinnai, N.; Sugiyama, H. Phosphorylation and calmodulin binding of the metabotropic glutamate receptor subtype 5 (mGluR5) are antagonistic in vitro. J. Biol. Chem., 1997, 272, 20291-20298.

[45] Piccinin, S.; Cinque, C.; Calo, L.; Molinaro, G.; Battaglia, G.; Maggi, L.; Nicoletti, F.; Melchiorri, D.; Eusebi, F.; Massey, P.V.; Bashir, Z.I. Interaction between ephrins and mGlu5 metabotropic glutamate receptors in the induction of long-term synaptic depression in the hippocampus. J. Neurosci., 2010, 30, $2835-2843$.

[46] Canela, L.; Fernandez-Duenas, V.; Albergaria, C.; Watanabe, M.; Lluis, C.; Mallol, J.; Canela, E.I.; Franco, R.; Lujan, R.; Ciruela, F. The association of metabotropic glutamate receptor type 5 with the neuronal $\mathrm{Ca} 2+$-binding protein 2 modulates receptor function. J. Neurochem., 2009, 111, 555-567. 
[47] Wang, H.; Westin, L.; Nong, Y.; Birnbaum, S.; Bendor, J.; Brismar, H.; Nestler, E.; Aperia, A.; Flajolet, M.; Greengard, P. Norbin is an endogenous regulator of metabotropic glutamate receptor 5 signaling. Science, 2009, 326, $1554-1557$.

[48] Anborgh, P.H.; Godin, C.; Pampillo, M.; Dhami, G.K.; Dale, L.B.; Cregan, S.P.; Truant, R.; Ferguson, S.S. Inhibition of metabotropic glutamate receptor signaling by the huntingtin-binding protein optineurin. J. Biol. Chem., 2005, $280,34840-34848$.

[49] Mao, L.M.; Liu, X.Y.; Zhang, G.C.; Chu, X.P.; Fibuch, E.E.; Wang, L.S.; Liu, Z.; Wang, J.Q. Phosphorylation of group I metabotropic glutamate receptors (mGluR1/5) in vitro and in vivo. Neuropharmacology, 2008, 55, 403-408.

[50] Croci, C.; Sticht, H.; Brandstatter, J.H.; Enz, R. Group I metabotropic glutamate receptors bind to protein phosphatase 1C. mapping and modeling of interacting sequences. J. Biol. Chem., 2003, 278, 50682-50690.

[51] Ishikawa, K.; Nash, S.R.; Nishimune, A.; Neki, A.; Kaneko, S.; Nakanishi, S. Competitive interaction of seven in absentia homolog-1A and $\mathrm{Ca} 2+/$ calmodulin with the cytoplasmic tail of group 1 metabotropic glutamate receptors. Genes Cells, 1999, 4, 381-390.

[52] Doumazane, E.; Scholler, P.; Zwier, J.M.; Eric, T.; Rondard, P.; Pin, J.P. A new approach to analyze cell surface protein complexes reveals specific heterodimeric metabotropic glutamate receptors. FASEB J., 2011, 25, 66-77.

[53] Romano, C.; Yang, W.L.; O'Malley, K.L. Metabotropic glutamate receptor 5 is a disulfide-linked dimer. J. Biol. Chem., 1996, 271, 28612-28616.

[54] Gonzalez-Maeso, J.; Ang, R.L.; Yuen, T.; Chan, P.; Weisstaub, N.V.; LopezGimenez, J.F.; Zhou, M.; Okawa, Y.; Callado, L.F.; Milligan, G.; Gingrich, 
J.A.; Filizola, M.; Meana, J.J.; Sealfon, S.C. Identification of a serotonin/glutamate receptor complex implicated in psychosis. Nature, 2008, 452, 93-97.

[55] Schroder, H.; Wu, D.F.; Seifert, A.; Rankovic, M.; Schulz, S.; Hollt, V.; Koch, T. Allosteric modulation of metabotropic glutamate receptor 5 affects phosphorylation, internalization, and desensitization of the micro-opioid receptor. Neuropharmacology, 2009, 56, 768-778.

[56] Ferre, S.; Karcz-Kubicha, M.; Hope, B.T.; Popoli, P.; Burgueno, J.; Gutierrez, M.A.; Casado, V.; Fuxe, K.; Goldberg, S.R.; Lluis, C.; Franco, R.; Ciruela, F. Synergistic interaction between adenosine A2A and glutamate mGlu5 receptors: Implications for striatal neuronal function. Proc. Natl. Acad. Sci. U. S. A., 2002, 99, 11940-11945.

[57] Cabello, N.; Gandia, J.; Bertarelli, D.C.; Watanabe, M.; Lluis, C.; Franco, R.; Ferre, S.; Lujan, R.; Ciruela, F. Metabotropic glutamate type 5, dopamine D(2) and adenosine $\mathrm{A}(2 \mathrm{a})$ receptors form higher-order oligomers in living cells. $J$. Neurochem., 2009, 109, 1497-1507.

[58] C.R. Gerfen, Basal ganglia, in: G. Paxinos (Ed.), The Rat Nervous System, Elsevier Academic Press, Amsterdam, 2004, pp. 445-508.

[59] Sesack, S.R.; Grace, A.A. Cortico-basal ganglia reward network: Microcircuitry. Neuropsychopharmacology, 2010, 35, 27-47.

[60] Smith, A.D.; Bolam, J.P. The neural network of the basal ganglia as revealed by the study of synaptic connections of identified neurones. Trends Neurosci., $1990,13,259-265$. 
[61] Ferre, S.; Fredholm, B.B.; Morelli, M.; Popoli, P.; Fuxe, K. Adenosinedopamine receptor-receptor interactions as an integrative mechanism in the basal ganglia. Trends Neurosci., 1997, 20, 482-487.

[62] Hettinger, B.D.; Lee, A.; Linden, J.; Rosin, D.L. Ultrastructural localization of adenosine A2A receptors suggests multiple cellular sites for modulation of GABAergic neurons in rat striatum. J. Comp. Neurol., 2001, 431, 331-346.

[63] Rosin, D.L.; Hettinger, B.D.; Lee, A.; Linden, J. Anatomy of adenosine A2A receptors in brain: Morphological substrates for integration of striatal function. Neurology, 2003, 61, S12-8.

[64] Ferre, S.; Borycz, J.; Goldberg, S.R.; Hope, B.T.; Morales, M.; Lluis, C.; Franco, R.; Ciruela, F.; Cunha, R. Role of adenosine in the control of homosynaptic plasticity in striatal excitatory synapses. J. Integr. Neurosci., 2005, 4, 445-464.

[65] Popoli, P.; Pezzola, A.; Torvinen, M.; Reggio, R.; Pintor, A.; Scarchilli, L.; Fuxe, K.; Ferre, S. The selective mGlu(5) receptor agonist CHPG inhibits quinpirole-induced turning in 6-hydroxydopamine-lesioned rats and modulates the binding characteristics of dopamine $\mathrm{D}(2)$ receptors in the rat striatum: Interactions with adenosine $\mathrm{A}(2 \mathrm{a})$ receptors. Neuropsychopharmacology, 2001, $25,505-513$.

[66] Kachroo, A.; Orlando, L.R.; Grandy, D.K.; Chen, J.F.; Young, A.B.; Schwarzschild, M.A. Interactions between metabotropic glutamate 5 and adenosine A2A receptors in normal and parkinsonian mice. J. Neurosci., 2005, $25,10414-10419$.

[67] Coccurello, R.; Breysse, N.; Amalric, M. Simultaneous blockade of adenosine A2A and metabotropic glutamate mGlu5 receptors increase their efficacy in 
reversing parkinsonian deficits in rats. Neuropsychopharmacology, 2004, 29, $1451-1461$.

[68] Ciruela, F.; Vilardaga, J.P.; Fernandez-Duenas, V. Lighting up multiprotein complexes: Lessons from GPCR oligomerization. Trends Biotechnol., 2010, $28,407-415$.

[69] Ferre, S.; Agnati, L.F.; Ciruela, F.; Lluis, C.; Woods, A.S.; Fuxe, K.; Franco, R. Neurotransmitter receptor heteromers and their integrative role in 'local modules': The striatal spine module. Brain Res. Rev., 2007, 55, 55-67.

[70] Ferre, S.; Ciruela, F.; Quiroz, C.; Lujan, R.; Popoli, P.; Cunha, R.A.; Agnati, L.F.; Fuxe, K.; Woods, A.S.; Lluis, C.; Franco, R. Adenosine receptor heteromers and their integrative role in striatal function. ScientificWorldJournal, 2007, 7, 74-85.

[71] Ferre, S.; Agnati, L.F.; Ciruela, F.; Lluis, C.; Woods, A.S.; Fuxe, K.; Franco, R. Neurotransmitter receptor heteromers and their integrative role in 'local modules': The striatal spine module. Brain Res. Rev., 2007, 55, 55-67.

[72] Fuxe, K.; Marcellino, D.; Borroto-Escuela, D.O.; Guescini, M.; FernandezDuenas, V.; Tanganelli, S.; Rivera, A.; Ciruela, F.; Agnati, L.F. Adenosinedopamine interactions in the pathophysiology and treatment of CNS disorders. CNS Neurosci. Ther., 2010, 16, e18-42.

[73] Cotzias, G.C.; Van Woert, M.H.; Schiffer, L.M. Aromatic amino acids and modification of parkinsonism. N. Engl. J. Med., 1967, 276, 374-379.

[74] Poewe, W. Treatments for parkinson disease--past achievements and current clinical needs. Neurology, 2009, 72, S65-73.

[75] Rascol, O.; Brooks, D.J.; Korczyn, A.D.; De Deyn, P.P.; Clarke, C.E.; Lang, A.E. A five-year study of the incidence of dyskinesia in patients with early 
parkinson's disease who were treated with ropinirole or levodopa. 056 study group. N. Engl. J. Med., 2000, 342, 1484-1491.

[76] Ferre, S.; von Euler, G.; Johansson, B.; Fredholm, B.B.; Fuxe, K. Stimulation of high-affinity adenosine A2 receptors decreases the affinity of dopamine D2 receptors in rat striatal membranes. Proc. Natl. Acad. Sci. U. S. A., 1991, 88, 7238-7241.

[77] Sweatt, J.D. The neuronal MAP kinase cascade: A biochemical signal integration system subserving synaptic plasticity and memory. J. Neurochem., 2001, 76, 1-10.

[78] Ferre, S.; O'Connor, W.T.; Fuxe, K.; Ungerstedt, U. The striopallidal neuron: A main locus for adenosine-dopamine interactions in the brain. J. Neurosci., 1993, 13, 5402-5406.

[79] Cho, K.; Bashir, Z.I. Cooperation between mglu receptors: A depressing mechanism? Trends Neurosci., 2002, 25, 405-411.

[80] Alagarsamy, S.; Marino, M.J.; Rouse, S.T.; Gereau, R.W.,4th; Heinemann, S.F.; Conn, P.J. Activation of NMDA receptors reverses desensitization of mGluR5 in native and recombinant systems. Nat. Neurosci., 1999, 2, 234-240.

[81] Vallano, A.; Fernandez-Duenas, V.; Pedros, C.; Arnau, J.M.; Ciruela, F. An update on adenosine A2A receptors as drug target in parkinson's disease. CNS Neurol. Disord. Drug Targets, 2011, 10, 659-669.

[82] Bonsi, P.; Cuomo, D.; Picconi, B.; Sciamanna, G.; Tscherter, A.; Tolu, M.; Bernardi, G.; Calabresi, P.; Pisani, A. Striatal metabotropic glutamate receptors as a target for pharmacotherapy in parkinson's disease. Amino Acids, 2007, 32, 189-195. 
[83] Fox, S.H.; Brotchie, J.M.; Lang, A.E. Non-dopaminergic treatments in development for parkinson's disease. Lancet Neurol., 2008, 7, 927-938.

[84] Chase, T.N.; Oh, J.D. Striatal dopamine- and glutamate-mediated dysregulation in experimental parkinsonism. Trends Neurosci., 2000, 23, S86-91.

[85] Dawson, T.M.; Ko, H.S.; Dawson, V.L. Genetic animal models of parkinson's disease. Neuron, 2010, 66, 646-661.

[86] Terzioglu, M.; Galter, D. Parkinson's disease: Genetic versus toxin-induced rodent models. FEBS J., 2008, 275, 1384-1391.

[87] Schwarting, R.K.; Huston, J.P. The unilateral 6-hydroxydopamine lesion model in behavioral brain research. analysis of functional deficits, recovery and treatments. Prog. Neurobiol., 1996, 50, 275-331.

[88] Breysse, N.; Baunez, C.; Spooren, W.; Gasparini, F.; Amalric, M. Chronic but not acute treatment with a metabotropic glutamate 5 receptor antagonist reverses the akinetic deficits in a rat model of parkinsonism. J. Neurosci., 2002, 22, 5669-5678.

[89] Breysse, N.; Amalric, M.; Salin, P. Metabotropic glutamate 5 receptor blockade alleviates akinesia by normalizing activity of selective basal-ganglia structures in parkinsonian rats. J. Neurosci., 2003, 23, 8302-8309.

[90] De Leonibus, E.; Manago, F.; Giordani, F.; Petrosino, F.; Lopez, S.; Oliverio, A.; Amalric, M.; Mele, A. Metabotropic glutamate receptors 5 blockade reverses spatial memory deficits in a mouse model of parkinson's disease. Neuropsychopharmacology, 2009, 34, 729-738.

[91] Chen, L.; Zhang, Q.J.; Liu, J.; Wang, S.; Ali, U.; Gui, Z.H.; Wang, Y. Chronic, systemic treatment with a metabotropic glutamate receptor 5 antagonist in 6- 
hydroxydopamine partially lesioned rats reverses abnormal firing of dopaminergic neurons. Brain Res., 2009, 1286, 192-200.

[92] Johnson, K.A.; Conn, P.J.; Niswender, C.M. Glutamate receptors as therapeutic targets for parkinson's disease. CNS Neurol. Disord. Drug Targets, 2009, 8, 475-491.

[93] Zigmond, M.J.; Berger, T.W.; Grace, A.A.; Stricker, E.M. Compensatory responses to nigrostriatal bundle injury. studies with 6-hydroxydopamine in an animal model of parkinsonism. Mol. Chem. Neuropathol., 1989, 10, 185-200.

[94] Samadi, P.; Gregoire, L.; Morissette, M.; Calon, F.; Hadj Tahar, A.; Dridi, M.; Belanger, N.; Meltzer, L.T.; Bedard, P.J.; Di Paolo, T. mGluR5 metabotropic glutamate receptors and dyskinesias in MPTP monkeys. Neurobiol. Aging, 2008, 29, 1040-1051.

[95] Levandis, G.; Bazzini, E.; Armentero, M.T.; Nappi, G.; Blandini, F. Systemic administration of an mGluR5 antagonist, but not unilateral subthalamic lesion, counteracts 1-DOPA-induced dyskinesias in a rodent model of parkinson's disease. Neurobiol. Dis., 2008, 29, 161-168.

[96] Johnston, T.H.; Fox, S.H.; Mclldowie, M.J.; Piggott, M.J.; Brotchie, J.M. Reduction of L-DOPA-induced dyskinesia by the selective metabotropic glutamate receptor 5 antagonist 3-[(2-methyl-1,3-thiazol-4-yl)ethynyl]pyridine in the 1-methyl-4-phenyl-1,2,3,6-tetrahydropyridine-lesioned macaque model of parkinson's disease. J. Pharmacol. Exp. Ther., 2010, 333, 865-873.

[97] Mela, F.; Marti, M.; Dekundy, A.; Danysz, W.; Morari, M.; Cenci, M.A. Antagonism of metabotropic glutamate receptor type 5 attenuates 1-DOPAinduced dyskinesia and its molecular and neurochemical correlates in a rat model of parkinson's disease. J. Neurochem., 2007, 101, 483-497. 
[98] Papa, S.M.; Chase, T.N. Levodopa-induced dyskinesias improved by a glutamate antagonist in parkinsonian monkeys. Ann. Neurol., 1996, 39, 574578.

[99] Bibbiani, F.; Oh, J.D.; Kielaite, A.; Collins, M.A.; Smith, C.; Chase, T.N. Combined blockade of AMPA and NMDA glutamate receptors reduces levodopa-induced motor complications in animal models of PD. Exp. Neurol., 2005, 196, 422-429.

[100] Nicoletti, F.; Bockaert, J.; Collingridge, G.L.; Conn, P.J.; Ferraguti, F.; Schoepp, D.D.; Wroblewski, J.T.; Pin, J.P. Metabotropic glutamate receptors: From the workbench to the bedside. Neuropharmacology, 2011, 60, 10171041.

[101] Lea, P.M.,4th; Faden, A.I. Metabotropic glutamate receptor subtype 5 antagonists MPEP and MTEP. CNS Drug Rev., 2006, 12, 149-166.

[102] Yashuara, A.; Chaki, S. Metabotropic glutamate receptors: Potential drugs targets for psychiatric disorders. Open Med Chem, 2010, 4, 20-36.

[103] Melancon, B.J.; Hopkins, C.R.; Wood, M.R.; Emmitte, K.A.; Niswender, C.M.; Christopoulos, A.; Conn, P.J.; Lindsley, C.W. Allosteric modulation of seven transmembrane spanning receptors: Theory, practice, and opportunities for central nervous system drug discovery. J. Med. Chem., 2012, 55, 14451464.

[104] Levenga, J.; Hayashi, S.; de Vrij, F.M.; Koekkoek, S.K.; van der Linde, H.C.; Nieuwenhuizen, I.; Song, C.; Buijsen, R.A.; Pop, A.S.; Gomezmancilla, B.; Nelson, D.L.; Willemsen, R.; Gasparini, F.; Oostra, B.A. AFQ056, a new mGluR5 antagonist for treatment of fragile X syndrome. Neurobiol. Dis., 2011, 42, 311-317. 
[105] Jacquemont, S.; Curie, A.; des Portes, V.; Torrioli, M.G.; Berry-Kravis, E.; Hagerman, R.J.; Ramos, F.J.; Cornish, K.; He, Y.; Paulding, C.; Neri, G.; Chen, F.; Hadjikhani, N.; Martinet, D.; Meyer, J.; Beckmann, J.S.; Delange, K.; Brun, A.; Bussy, G.; Gasparini, F.; Hilse, T.; Floesser, A.; Branson, J.; Bilbe, G.; Johns, D.; Gomez-Mancilla, B. Epigenetic modification of the FMR1 gene in fragile $\mathrm{X}$ syndrome is associated with differential response to the mGluR5 antagonist AFQ056. Sci. Transl. Med., 2011, 3, 64ra1.

[106] Kenny, P.J. Emerging therapeutic targets for the treatment of nicotine addiction. Expert Rev Clin Pharmacol, 2009, 2, 221-225.

[107] Blondeau, K. Treatment of gastro-esophageal reflux disease: The new kids to block. Neurogastroenterol. Motil., 2010, 22, 836-840.

[108] Berg, D.; Godau, J.; Trenkwalder, C.; Eggert, K.; Csoti, I.; Storch, A.; Huber, H.; Morelli-Canelo, M.; Stamelou, M.; Ries, V.; Wolz, M.; Schneider, C.; Di Paolo, T.; Gasparini, F.; Hariry, S.; Vandemeulebroecke, M.; Abi-Saab, W.; Cooke, K.; Johns, D.; Gomez-Mancilla, B. AFQ056 treatment of levodopainduced dyskinesias: Results of 2 randomized controlled trials. Mov. Disord., 2011, 26, 1243-1250.

[109] Stocchi, F.; Destee, A.; Hattori, N.; Hauser, R.A.; Lang, A.E.; Poewe, W.; Rascol, O.; Stacy, M.; Tolosa, E.; Trenkwalder, C.; Gao, H.; Nagel, J.; GomezMancilla, B.; Merschhemke, M.; Tekin, S.; Abi-Saab, W. A 13-week, doubleblind, placebo-controlled study of AFQ056, a metabotropic glutamate receptor 5 antagonist in Parkinson's disease patients with moderate-to-severe L-dopa induced dyskinesia. Mov Dis Soc Meeting, 2011, late breaking abstract LB12, .

[110] Kumar, R.; Hauser, R.; Mostillo, J.; Dronanraju, N.; Graf, A.; Kenney, C.; Merschhemke, M. A 6-week, double-blind, multicenter RCT in Parkinson's 
disease patients to explore the efficacy and safety of AFQ056 when combined with increased dose of L-dopa. Mov Disor, 2012, 27 Suppl. 1, S126.

[111] Colosimo, C.; Martinez-Martin, P.; Fabbrini, G.; Hauser, R.A.; Merello, M.; Miyasaki, J.; Poewe, W.; Sampaio, C.; Rascol, O.; Stebbins, G.T.; Schrag, A.; Goetz, C.G. Task force report on scales to assess dyskinesia in parkinson's disease: Critique and recommendations. Mov. Disord., 2010, 25, 1131-1142.

[112] Chakraborty, A.; Ufer, M.; Bhad, P.; Vandemeulebroecke, M.; GomezMancilla, B.; Bell, D.; Winter, S. Lack of pharmacokinetic interaction between the novel mGluR5 antagonist AFQ056 and levodopa/carbidopa in healthy volunteers. Mov Disor, 2012, 27 Suppl 1, 456.

[113] Ciruela, F.; Fernandez-Duenas, V.; Llorente, J.; Borroto-Escuela, D.; Cuffi, M.L.; Carbonell, L.; Sanchez, S.; Agnati, L.F.; Fuxe, K.; Tasca, C.I. G proteincoupled receptor oligomerization and brain integration: Focus on adenosinergic transmission. Brain Res., 2012, 1476, 86-95.

[114] Hernandez-Lopez, S.; Tkatch, T.; Perez-Garci, E.; Galarraga, E.; Bargas, J.; Hamm, H.; Surmeier, D.J. D2 dopamine receptors in striatal medium spiny neurons reduce L-type Ca2+ currents and excitability via a novel PLC[beta]1IP3-calcineurin-signaling cascade. J. Neurosci., 2000, 20, 8987-8995.

[115] Ciruela, F.; Gomez-Soler, M.; Guidolin, D.; Borroto-Escuela, D.O.; Agnati, L.F.; Fuxe, K.; Fernandez-Duenas, V. Adenosine receptor containing oligomers: Their role in the control of dopamine and glutamate neurotransmission in the brain. Biochim. Biophys. Acta, 2011, 1808, 12451255. 
Table 1. Randomised Clinical Trials with AFQ056 in Parkinson's Patients with L-DOPA Induced Dyskinesias (LID).

\begin{tabular}{|c|c|c|c|c|c|}
\hline $\begin{array}{l}\text { Authors (year) } \\
\text { study countries }\end{array}$ & $\begin{array}{l}\text { Phase and design } \\
\text { clinical trial }\end{array}$ & Patients & $\begin{array}{c}\text { Treatment } \\
\text { (drugs, doses, length) }\end{array}$ & $\begin{array}{l}\text { Primary } \\
\text { outcome }\end{array}$ & $\begin{array}{c}\text { Other } \\
\text { outcomes }\end{array}$ \\
\hline $\begin{array}{l}\text { Berg D et al. } \\
(2007-2008) \\
\text { Germany } \\
{[108]}\end{array}$ & $\begin{array}{l}\bullet \text { Phase II } \\
\text { Multicenter, } \\
\text { randomized, } \\
\text { double blind, } \\
\text { parallel-group, } \\
\text { placebo- } \\
\text { controlled } \\
\text { (randomisation } \\
\text { ratio 1:1) }\end{array}$ & $\begin{array}{l}31 \text { subjects } \\
\text { with } \\
\text { moderate to } \\
\text { severe LID }\end{array}$ & $\begin{array}{l}\bullet \text { AFQ056 }(\mathrm{n}=15) \\
\text { dose-titration: } \\
\text { Days 1-4: } 25 \mathrm{mg} \text { bid } \\
\text { Days 5-8: } 50 \mathrm{mg} \text { bid } \\
\text { Days 9-12: } 100 \mathrm{mg} \\
\text { bid } \\
\text { Days 13-16: } 150 \mathrm{mg} \\
\text { bid } \\
\text { Placebo }(\mathrm{n}=16)\end{array}$ & $\begin{array}{l}- \text { LFADLDS } \\
\text { Scale } \\
\text {-UPDRS-III } \\
\text { (motor } \\
\text { function) }\end{array}$ & $\begin{array}{l}- \text { UPDRS -IV } \\
\text { (motor } \\
\text { complicationsi } \\
\text { tems 32-33) } \\
\text { - mAIMS }\end{array}$ \\
\hline $\begin{array}{l}\text { Berg D et al. } \\
(2009) \\
\text { Germany [108] }\end{array}$ & $\begin{array}{l}\bullet \text { Phase II } \\
\text { Multicenter, } \\
\text { randomized, } \\
\text { double blind, } \\
\text { parallel-group, } \\
\text { placebo- } \\
\text { controlled } \\
\text { (randomisation } \\
\text { ratio 1:1) }\end{array}$ & $\begin{array}{l}28 \text { subjects } \\
\text { with severe } \\
\text { LID }\end{array}$ & $\begin{array}{l}\text {-AFQ056 (n=14) } \\
\text { dose-titration: } \\
\text { Days 1-4: } 25 \mathrm{mg} \text { bid } \\
\text { Days 5-8: } 50 \mathrm{mg} \text { bid } \\
\text { Days 9-12: } 100 \mathrm{mg} \\
\text { bid } \\
\text { Days 13-16: } 150 \mathrm{mg} \\
\text { bid } \\
\text { Placebo }(\mathrm{n}=14)\end{array}$ & $\begin{array}{l}\text { •mAIMS } \\
\text { (abnormal } \\
\text { movements) } \\
\text { •UPDRS-III }\end{array}$ & $\begin{array}{l}\bullet \text { UPDRS - IV } \\
\text { items 32-33 } \\
\bullet \text { LFADLDS }\end{array}$ \\
\hline $\begin{array}{l}\text { Stocchi et al } \\
(2009-2010) \\
\text { Australia, } \\
\text { Canada, } \\
\text { Finland, } \\
\text { France, } \\
\text { Germany, Italy, } \\
\text { Japan, Spain } \\
\text { [109] }\end{array}$ & $\begin{array}{l}\bullet \text { Phase II } \\
\text { Multicenter, } \\
\text { randomized, } \\
\text { double blind, } \\
\text { parallel-group, } \\
\text { placebo- } \\
\text { controlled } \\
\text { (randomisation } \\
\text { ratio 1:1:1:12:3) }\end{array}$ & $\begin{array}{l}197 \\
\text { subjects } \\
\text { with } \\
\text { moderate to } \\
\text { severe LID }\end{array}$ & $\begin{array}{l}\bullet \text { AFQ056 }(\mathrm{n}=133) \\
\text { Fixed-dose } \\
10 \mathrm{mg} \text { bid } \\
25 \mathrm{mg} \text { bid } \\
50 \mathrm{mg} \text { bid } \\
75 \mathrm{mg} \text { bid } \\
100 \mathrm{mg} \text { bid } \\
/ 12 \text { weeks } \\
\text { Placebo }(\mathrm{n}=64)\end{array}$ & $\bullet \mathrm{mAIMS}$ & $\begin{array}{l}\text {-PDYS-26 } \\
\text {-CGIC } \\
\text {-PGIC } \\
\text {-UPDRS - IV } \\
\text { items 32-33 } \\
\text {-UPDRS-III }\end{array}$ \\
\hline $\begin{array}{l}\text { Kumar et al } \\
(2012) \\
\text { United States } \\
{[110]}\end{array}$ & $\begin{array}{l}- \text { Phase II } \\
\text { Multicenter, } \\
\text { randomized, } \\
\text { double blind, } \\
\text { parallel-group, } \\
\text { placebo- } \\
\text { controlled } \\
\text { (randomisation } \\
\text { ratio 1:1) }\end{array}$ & $\begin{array}{l}14 \text { subjects } \\
\text { with } \\
\text { moderate to } \\
\text { severe LID }\end{array}$ & $\begin{array}{l}\bullet \text { AFQ056 }(\mathrm{n}=7) \\
\text { dose-titration: } \\
25 \text { to } 100 \mathrm{mg} \text { bid / } 6 \\
\text { weeks } \\
\text { Placebo }(\mathrm{n}=7)\end{array}$ & $\begin{array}{lr}\text {-LOCF } & \text { in } \\
\text { total } & \text { OFF } \\
\text { time } & \end{array}$ & $\begin{array}{l}\text {-LOCF in on } \\
\text { time with } \\
\text { dyskinesia } \\
\text {-UPDRS-III } \\
\text { - mAIMS } \\
\text { - UDysRS } \\
\text { - CGIC } \\
\text { - PGIC }\end{array}$ \\
\hline
\end{tabular}

PD: Parkinson's disease; LID: L-DOPA-induced dyskinesia; bid: twice a day; LFADLDS: Lang-Fahn Activities of Daily Living Dyskinesia Scale; UPDRS III: Unified Parkinson's Disease Rating Scale-part III; mAIMS: modified Abnormal Involuntary Movements Scale: UPDRS IV: Unified Parkinson's disease Rating Scale-part IV; LOCF: change from baseline to the last-observation-carried-forward; PDYS-26 Parkinson's disease dyskinesia scale; CGIC: clinician-rated global impression of change; PGIC: patient-rated global impression of change; UDysRS Unified Dyskinesia Rating Scale. 
Table 2. Ongoing clinical trials testing drugs acting on $\mathbf{m G l u}_{5}$ receptor registred with www.ClinicalTrials.gov (on October 19, 2012).

\begin{tabular}{|c|c|c|c|c|c|c|c|}
\hline ID & Sponsor & Status & $\begin{array}{c}\text { Design/ } \\
\text { Clinical trial } \\
\text { phase }\end{array}$ & $\begin{array}{l}\text { Experimental drug, } \\
\text { dose and duration }\end{array}$ & Control & $\begin{array}{l}\text { Size } \\
\text { (n) }\end{array}$ & $\begin{array}{l}\text { Condition } \\
\text { PD }\end{array}$ \\
\hline NCT01385592 & Novartis & ANR & $\begin{array}{l}\text { DB RCT } \\
\text { Phase II }\end{array}$ & $\begin{array}{c}\text { AFQ056 } \\
100 \mathrm{mg} \\
12 \text { weeks }\end{array}$ & Placebo & 63 & $\begin{array}{l}\text { PD with } \\
\text { moderate to } \\
\text { severe LID }\end{array}$ \\
\hline NCT01491529 & Novartis & $\begin{array}{c}\mathrm{R} \\
\text { (ESCD } \\
\text { April } \\
2013)\end{array}$ & $\begin{array}{l}\text { DB RCT } \\
\text { Phase II }\end{array}$ & $\begin{array}{l}\text { AFQ056 } \\
\text { dose-titration: } \\
-150 \mathrm{mg} \text { bid } \\
-200 \mathrm{mg} \text { bid } \\
2 \text { and } 4 \text { weeks }\end{array}$ & Placebo & 140 & $\begin{array}{l}\text { PD with } \\
\text { severe LID }\end{array}$ \\
\hline NCT01173731 & Novartis & $\begin{array}{c}\text { EI } \\
(\text { ESCD } \\
\text { Decemb } \\
\text { er 2014) }\end{array}$ & $\begin{array}{l}\text { OL, SG } \\
\text { NRCT } \\
\text { Phase II }\end{array}$ & $\begin{array}{l}\text { AFQ056 } \\
\text { NR dose } \\
3.5 \text { years }\end{array}$ & - & 119 & PD with LID \\
\hline NCT01491932 & Novartis & $\begin{array}{c}\mathrm{R} \\
\text { (ESCD } \\
\text { October } \\
2015)\end{array}$ & $\begin{array}{l}\text { OL, SG } \\
\text { NRCT } \\
\text { Phase II }\end{array}$ & $\begin{array}{c}\text { AFQ056 } \\
\text { dose-titration bid or } \\
\text { the highest tolerated } \\
3 \text { years }\end{array}$ & - & 142 & PD with LID \\
\hline
\end{tabular}

ID: ClinicalTrials.gov Identifier; Size (n): Estimated enrolment of the number of patients; PD: Parkinson's disease; Status: C (Completed) the study has been completed; R (Recruiting) the study is currently recruiting participants; ANR (Active, no Recruiting) the study is ongoing, but not recruiting participants; EI (enrolling by invitation) the study is enrolling participants by invitation only. ESCD: Estimated study completion data; DB: Double blind masking; OL: Open label masking; SG: Single group; RCT: randomised clinical trial; NRCT: non-randomised clinical trial; bid: twice a day; LID: L-DOPA-induced dyskinesia; NR: not reported. 
Table 3. Baseline demographic and background characteristics of subjects.

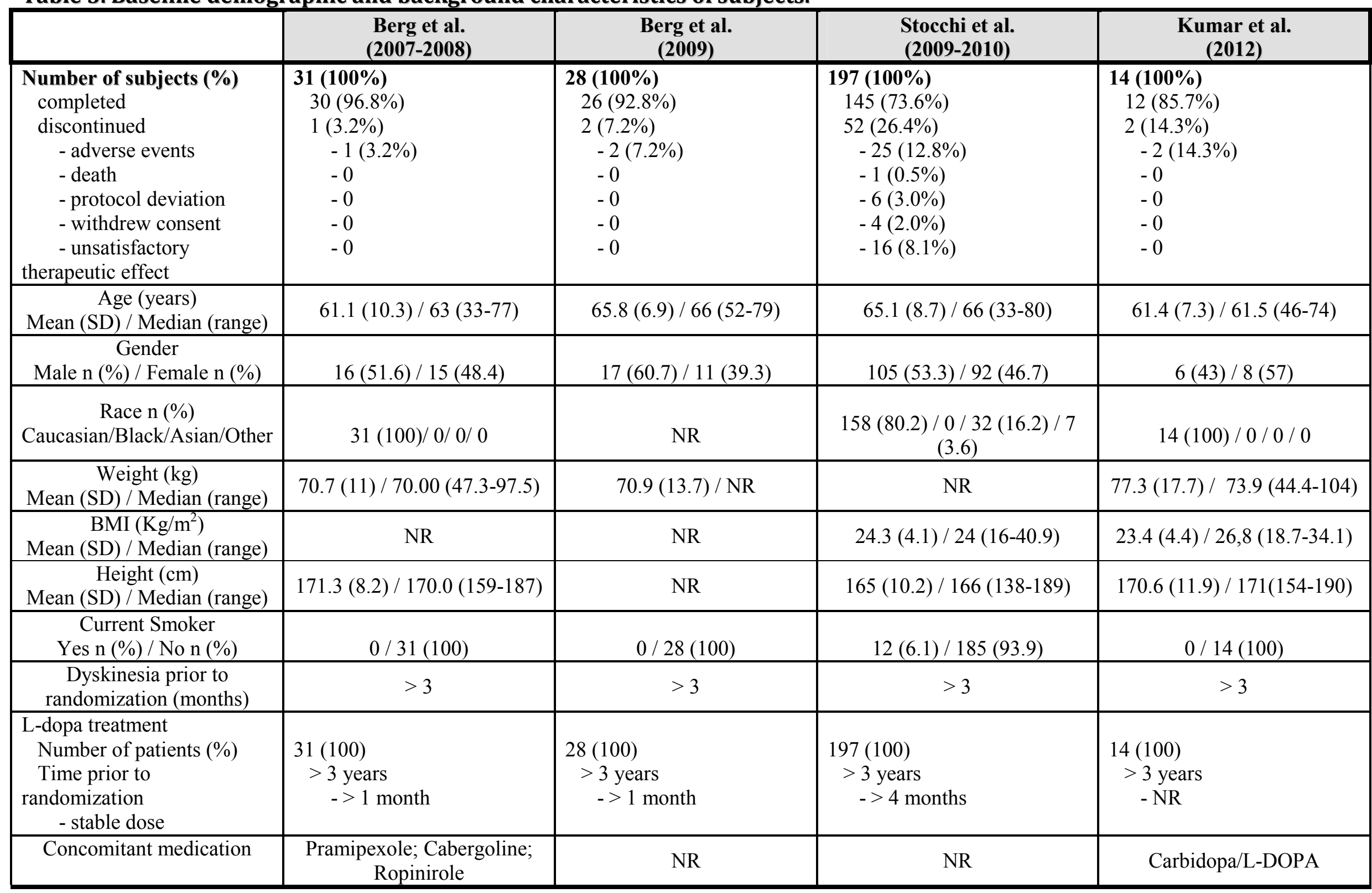

NR: No reported 
Table 4. Efficacy Results: Mean change from baseline to day 16 on primary and secondary outcomes.

\begin{tabular}{|c|c|c|c|c|c|c|}
\hline \multirow{2}{*}{ Scale } & \multicolumn{3}{|c|}{$\begin{array}{c}\text { Berg et al } \\
(2007-2008)\end{array}$} & \multicolumn{3}{|c|}{$\begin{array}{l}\text { Berg et al. } \\
\text { (2009) }\end{array}$} \\
\hline & AFQ056 & Placebo & $\begin{array}{c}\text { Difference } \\
(90 \% \mathrm{CI})\end{array}$ & AFQ056 & Placebo & $\begin{array}{c}\text { Difference } \\
(90 \% \mathrm{CI})\end{array}$ \\
\hline $\begin{array}{l}\text { LFADLDS } \\
\text { Day } 16\end{array}$ & -4.60 & -1.57 & $\begin{array}{c}-3.02 \\
(-5.12,-0.93)^{*}\end{array}$ & -3.84 & -2.30 & $\begin{array}{c}-1.54 \\
(-3.69,-0.61)\end{array}$ \\
\hline $\begin{array}{l}\text { mAIMS } \\
\text { Day } 16\end{array}$ & -6.93 & -1.63 & $\begin{array}{c}-5.31 \\
(-7.15,-3.46)^{*}\end{array}$ & -9.75 & -4.84 & $\begin{array}{c}-4.91 \\
(-8.61,- \\
1.22)^{*}\end{array}$ \\
\hline $\begin{array}{l}\text { UPDRS-III } \\
\text { Day } 16\end{array}$ & -2.00 & -4.25 & $\begin{array}{c}2.24 \\
(-1.65,-6.14)\end{array}$ & -6.09 & -2.79 & $\begin{array}{c}-3.30 \\
(-8.39,- \\
1.79)\end{array}$ \\
\hline $\begin{array}{l}\text { UPDRS-IV } \\
\text { Day } 16\end{array}$ & -1.99 & -0.82 & $\begin{array}{c}-1.16 \\
(-1.92,-0.41)^{*}\end{array}$ & -2.56 & -0.98 & $\begin{array}{c}-1.58 \\
(-2.32,- \\
0.84)^{*}\end{array}$ \\
\hline
\end{tabular}

LFADLDS: Lang-Fahn Activities of Daily Living Dyskinesia Scale; mAIMS: modified Abnormal Involuntary; UPDRS III: Unified Parkinson's disease Rating Scale-part III, Movements Scale; UPDRS IV: Unified Parkinson's disease Rating Scale-part IV (items 3233). ${ }^{*}$ P-value $<0.05$ when compared with placebo. 
Table 5. Efficacy Results: Mean change from baseline to week 12 on primary outcome.

\begin{tabular}{|c|c|c|c|c|c|}
\hline & \multicolumn{5}{|c|}{ Stocchi et al } \\
\hline & $\begin{array}{c}\text { mAIMS } \\
\text { baseline } \\
\text { Mean (SD) }\end{array}$ & $\begin{array}{c}\text { mAIMS } \\
\text { week } 12 \\
\text { Mean (SD) }\end{array}$ & $\begin{array}{c}\text { Adjusted } \\
\text { change from } \\
\text { baseline } \\
\text { Mean (SD) }\end{array}$ & $\begin{array}{l}\text { Difference } \\
(95 \% \mathrm{CI})\end{array}$ & $\begin{array}{c}\text { Pair wise } \\
\text { comparisons } \\
\text { p-value }^{b}\end{array}$ \\
\hline Placebo & $13.4(4.71)$ & $10.4(5.35)$ & $-2.9(0.61)$ & & \\
\hline $\begin{array}{c}\text { AFQ056 } \\
20 \mathrm{mg} \text { daily }\end{array}$ & $14.5(4.64)$ & $11.3(5.73)$ & $-2.7(0.99)$ & $0.2(-2.7,3.2)$ & 0.743 \\
\hline $\begin{array}{c}\text { AFQ056 } \\
50 \text { mg daily }\end{array}$ & $12.9(5.03)$ & $7.6(6.57)$ & $-5.5(0.99)$ & $\begin{array}{c}-2.6(-5.5 \\
0.4)\end{array}$ & 0.046 \\
\hline $\begin{array}{c}\text { AFQ056 } \\
100 \mathrm{mg} \text { daily }\end{array}$ & $13.5(5.29)$ & $9.8(5.90)$ & $-3.6(0.99)$ & $\begin{array}{c}-0.6(-3.6 \\
2.3)\end{array}$ & 0.571 \\
\hline $\begin{array}{c}\text { AFQ056 } \\
150 \mathrm{mg} \text { daily }\end{array}$ & $13.9(5.08)$ & $10.8(4.50)$ & $-2.8(0.99)$ & $0.1(-2.8,3.1)$ & 0.743 \\
\hline $\begin{array}{c}\text { AFQ056 } \\
200 \text { mg daily }\end{array}$ & $13.2(4.999$ & $7.5(5.00)$ & $-5.7(0.75)$ & $\begin{array}{c}-2.8(-5.2,- \\
0.4)\end{array}$ & 0.007 \\
\hline $\begin{array}{c}\text { Overall F-test } \\
\text { p-value }\end{array}$ & & & & & 0.015 \\
\hline
\end{tabular}

mAIMS: modified Abnormal Involuntary Movement Scale. A negative change from baseline indicates improvement. An analysis of covariance (ANCOVA) model was used with baseline value as a covariate and treatment and country as factors.

${ }^{\mathrm{a}}$ The overall F-test tests if at least one dose differs from placebo.

${ }^{\mathrm{b}}$ Comparison of each dose group with placebo were made at the one-side error rate of $2.5 \%$. 
Table 6. Most frequent adverse events possible or probably related to study-drug reported in subjects in either treatment group, by system organ class and preferred term (Safety Population)

\begin{tabular}{|c|c|c|}
\hline MedDRA System Organ Class/Preferred term & $\begin{array}{c}\text { AFQ056 (N=237) } \\
\text { n (\%) }\end{array}$ & $\begin{array}{c}\text { Placebo }(\mathrm{N}=100) \\
n(\%)\end{array}$ \\
\hline \multicolumn{3}{|l|}{ Cardiac disorders } \\
\hline Tachycardia & $4(1.7)$ & $0(-)$ \\
\hline \multicolumn{3}{|l|}{ Eye disorder } \\
\hline Vision blurred/disturbed/impaired & $6(2.5)$ & $0(-)$ \\
\hline \multicolumn{3}{|l|}{ Gastrointestinal disorders } \\
\hline Diarrhoea & $7(3.0)$ & $3(3.0)$ \\
\hline Nausea & $9(3.8)$ & $8(8.0)$ \\
\hline Vomiting & $2(0.8)$ & $0(-)$ \\
\hline Constipation & $1(0.4)$ & $2(2.0)$ \\
\hline Dry mouth & $1(0.4)$ & $3(3.0)$ \\
\hline Toothache & $0(-)$ & $2(2.0)$ \\
\hline \multicolumn{3}{|l|}{ General disorders and administration site conditions } \\
\hline Fatigue & $9(3.8)$ & $4(4.0)$ \\
\hline Agitation & $2(0.8)$ & $1(1.0)$ \\
\hline Asthenia & $0(-)$ & $2(2.0)$ \\
\hline \multicolumn{3}{|l|}{ Infections and infestations } \\
\hline Nasopharyngitis & $8(3.4)$ & $0(-)$ \\
\hline Urinary tract infection & $4(1.7)$ & $0(-)$ \\
\hline \multicolumn{3}{|l|}{ Injury, poisoning and procedural complications } \\
\hline Fall & $5(2.1)$ & $1(1.0)$ \\
\hline Skin injury & $1(0.4)$ & $0(-)$ \\
\hline Traumatic haematoma & $1(0.4)$ & $0(-)$ \\
\hline \multicolumn{3}{|l|}{ Investigations } \\
\hline Blood pressure increased & $2(0.8)$ & $1(1.0)$ \\
\hline \multicolumn{3}{|l|}{ Musculoskeletal and connective tissue disorders } \\
\hline Pain in extremity & $6(2.5)$ & $0(-)$ \\
\hline Arthralgia & $3(1.3)$ & $0(-)$ \\
\hline Torticollis & $1(0.4)$ & $0(-)$ \\
\hline Rhabdomyolysis & $1(0.4)$ & $0(-)$ \\
\hline \multicolumn{3}{|l|}{ Nervous systems disorders } \\
\hline Dizziness & $36(15.2)$ & $5(5.0)$ \\
\hline Dyskinesia & $17(7.2)$ & $18(18.0)$ \\
\hline Headache & $6(2.5)$ & $3(3.0)$ \\
\hline Parkinson's disease ${ }^{*}$ & $2(0.8)$ & $2(2.0)$ \\
\hline Hyperkinesia & $1(0.4)$ & $1(1.0)$ \\
\hline \multicolumn{3}{|l|}{ Psychiatric disorders } \\
\hline Hallucination & $9(3.8)$ & $1(1.0)$ \\
\hline Confusional state & $8(3.4)$ & $0(-)$ \\
\hline Insomnia & $8(3.4)$ & $1(1.0)$ \\
\hline Illusion & $6(2.5)$ & $4(4.0)$ \\
\hline Nervousness & $4(1.7)$ & $0(-)$ \\
\hline Psychotic disorder & $3(1.3)$ & $0(-)$ \\
\hline Euphoric mood & $4(1.7)$ & $0(-)$ \\
\hline Restlessness & $1(0.4)$ & $0(-)$ \\
\hline \multicolumn{3}{|l|}{ Reproductive system and breast disorders } \\
\hline Priapism & $2(0.8)$ & $0(-)$ \\
\hline \multicolumn{3}{|l|}{ Skin and subcutaneous tissue disorders } \\
\hline Skin burning sensation & $2(0.9)$ & $0(-)$ \\
\hline
\end{tabular}

*Aggravation of symptoms. 
Figure 1 Vallano et al., 2012
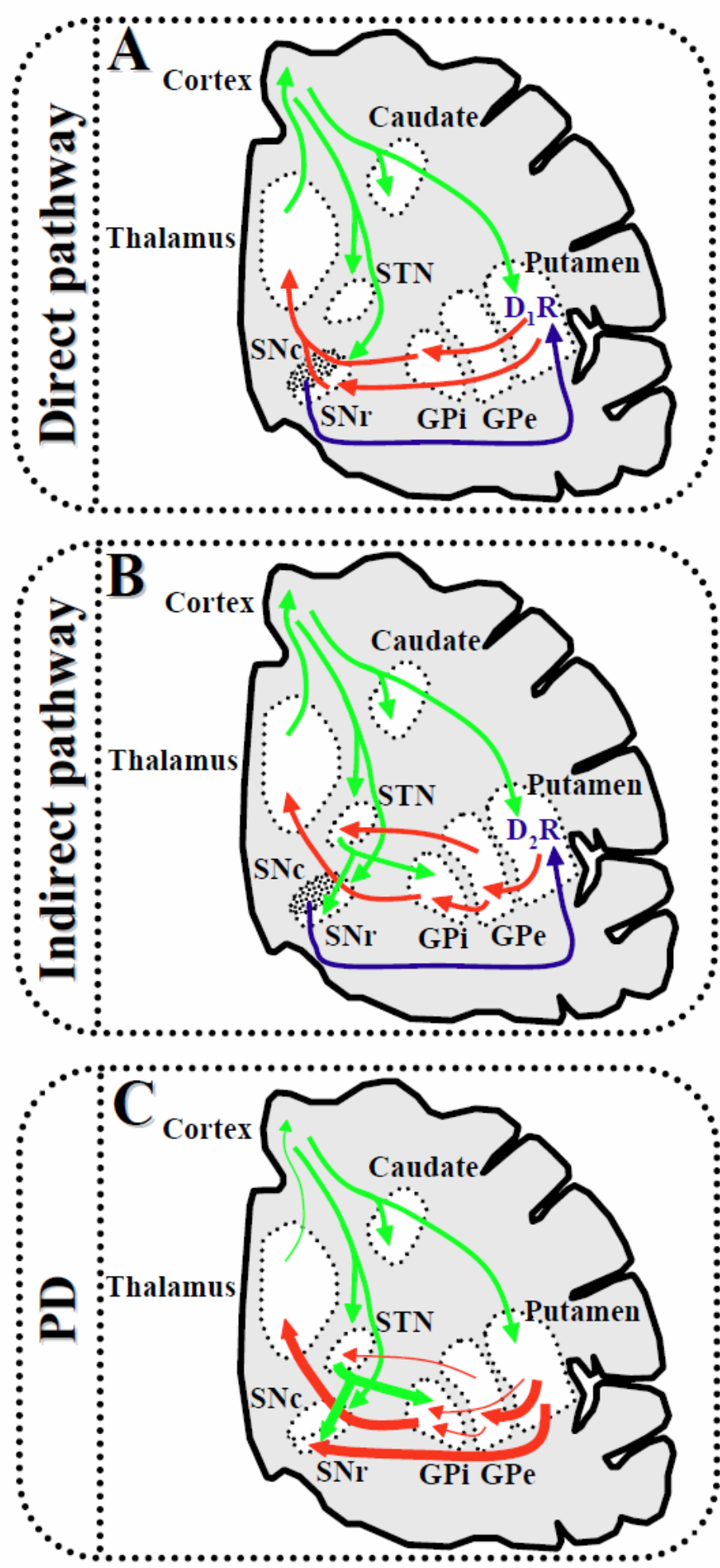
Figure 2 Vallano et al., 2012

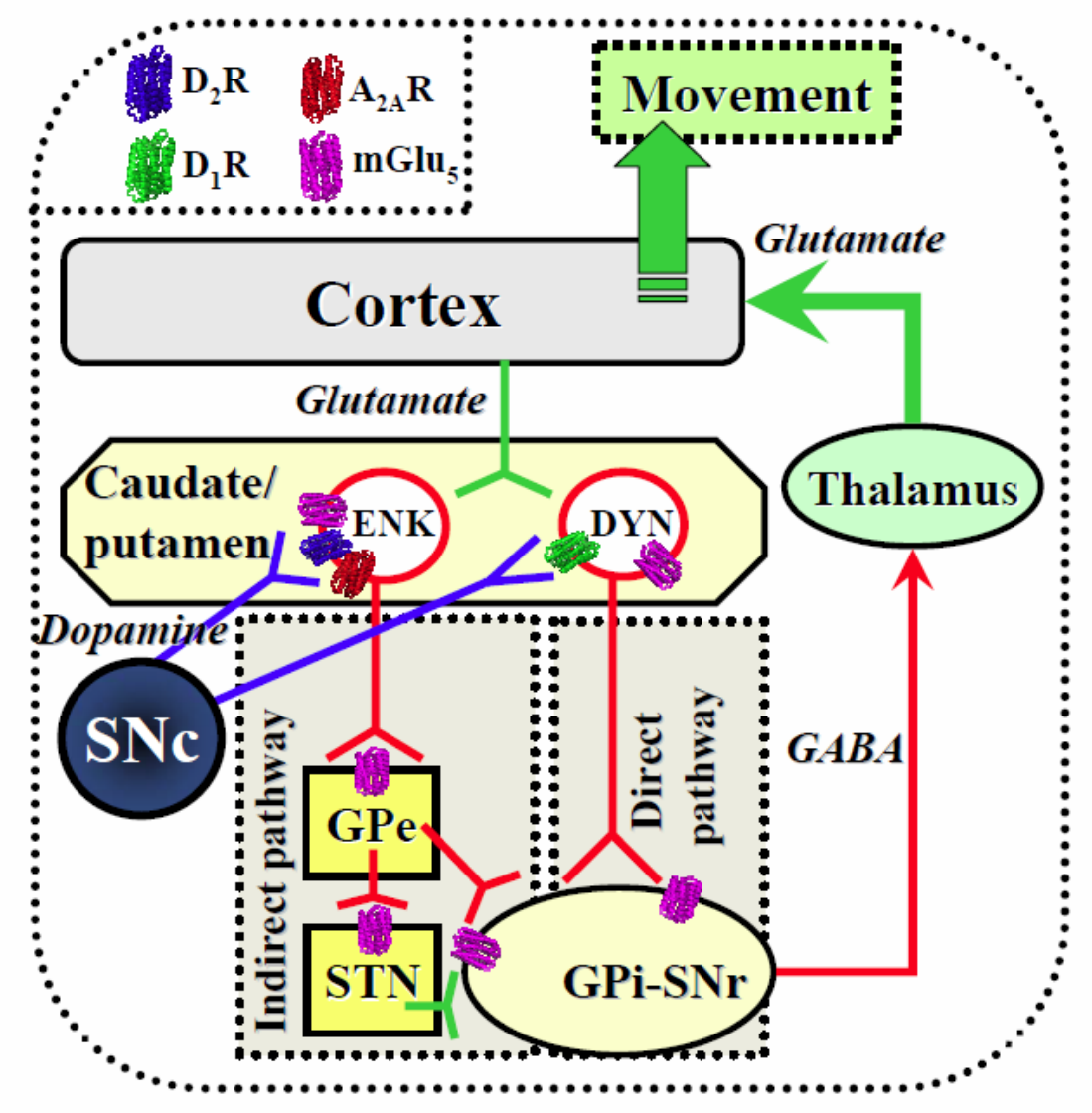


Figure 3 Vallano et al., 2012

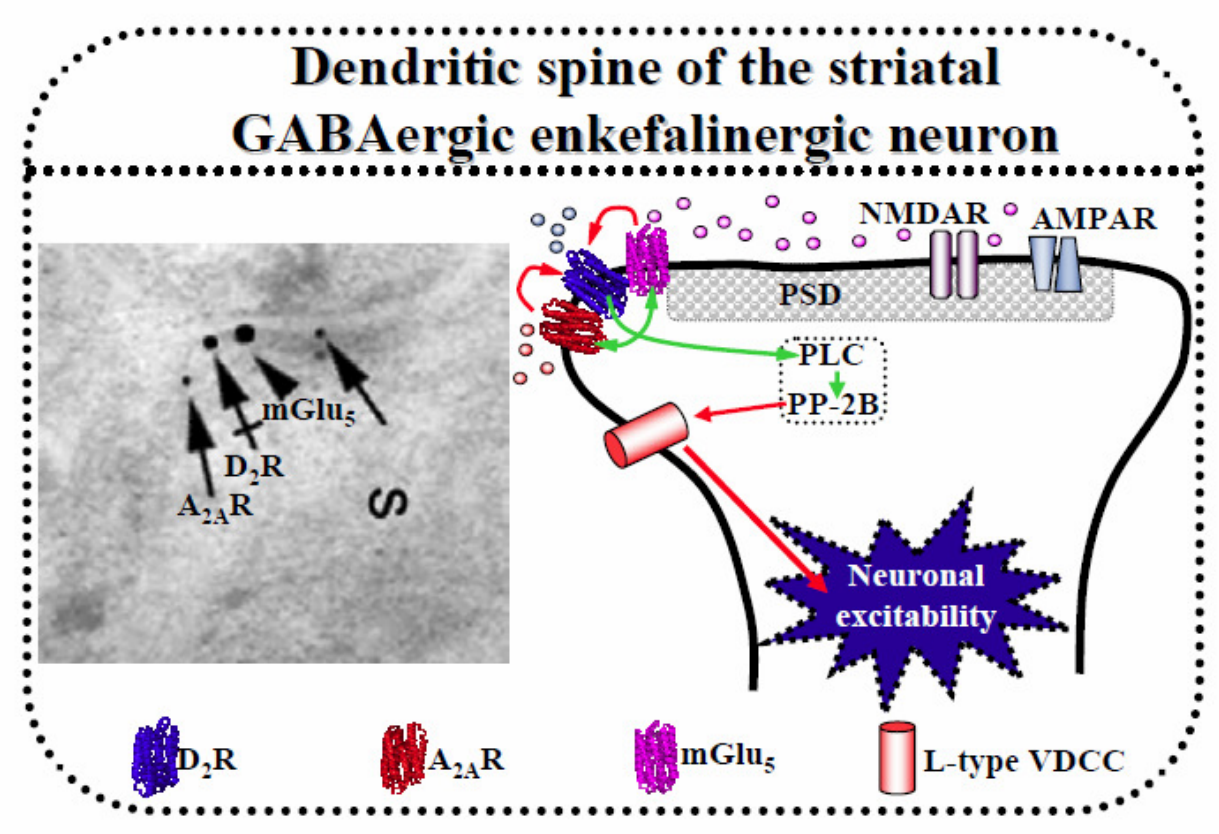

